\title{
Groenlandaspidid Placoderm Fishes from the Late Devonian of North America
}

\author{
Edward B. Daeschler, ${ }^{1 *}$ Anna C. Frumes $^{2}$ And C. Frederick Mullison ${ }^{1}$ \\ ${ }^{1}$ Vertebrate Zoology, Academy of Natural Sciences of Philadelphia, \\ 1900 Benjamin Franklin Parkway, Philadelphia, PA 19103, United States of America \\ daeschler@acnatsci.org \\ ${ }^{2}$ Integrative Biology, University of California at Berkeley, \\ 3060 Valley Life Science Building, CA 94720-3140, United States of America
}

\begin{abstract}
Two new taxa of groenlandaspidid fish (Placodermi: Arthrodira) from non-marine deposits of the Catskill Formation (Upper Devonian) at Red Hill, Clinton County, Pennsylvania, USA, are the first to be described from North America outside of Greenland. Groenlandaspis pennsylvanica n.sp. is known only from isolated trunk elements that are quite similar to Groenlandaspis antarctica Ritchie, 1975. Groenlandaspis pennsylvanica $\mathrm{n} . \mathrm{sp}$. is characterized by distinct features of the median dorsal (MD), posterior dorsolateral (PDL), and anterior dorsolateral (ADL) plates. Turrisaspis elektor n.gen. and n.sp. is a smaller form with a high median dorsal plate (MD) and tall, narrow elements of the dorsolateral trunk shield, particularly the PDL, giving this taxon a distinctively short, high trunk shield. The head shield of Turrisaspis elektor has a divided pineal plate and the postmarginal plate makes contact with the postorbital plate, excluding the marginal plate from the lateral margin of the head shield. Groenlandaspis pennsylvanica $\mathrm{n}$.sp. is a rare faunal component at the Red Hill site whereas Turrisaspis elektor is very common. The large sample size of Turrisaspis elektor provides a glimpse at ontogenetic and individual variation within this taxon.
\end{abstract}

Daeschler, Edward B., Anna C. Frumes \& C. Frederick Mullison, 2003. Groenlandaspidid placoderm fishes from the Late Devonian of North America. Records of the Australian Museum 55(1): 45-60.

Groenlandaspidid placoderms have been reported from strata as old as Early Devonian, but the diversity is particularly well documented during the Late Devonian. The earliest known member of the family is Tiaraspis subtilis from the Early Devonian of Germany (Gross, 1933, 1962; Schultze, 1984). Other groenlandaspidids from the Euramerican Province are Groenlandaspis mirabilis from the Famennian of eastern Greenland (Heintz, 1932), and Groenlandaspis disjectus from Ireland (Woodward, 1891; Ritchie, 1975). Gross (1965) discusses isolated groenlandaspidid median dorsal elements from the Famennian of
Belgium. The Gondwanan Province has produced Groenlandaspis theroni from the Givetian of South Africa (Chaloner et al., 1980; Anderson et al., 1999), Groenlandaspis antarctica and Boomeraspis goujeti from the late Givetian to early Frasnian Aztec Siltstone in Victoria Land, Antarctica (Ritchie, 1975; Long, 1995), Groenlandaspis seni from the ?Frasnian of Turkey (Janvier \& Ritchie, 1977), and Groenlandaspis riniensis and Africanaspis doryssa from the Famennian of South Africa (Long et al., 1997). Janvier \& Ritchie (1977, fig. 1E) and Blieck et al. (1980) discuss groenlandaspidid material from the Eifelian of Iran. Janvier 
Table 1. Red Hill flora and fauna.

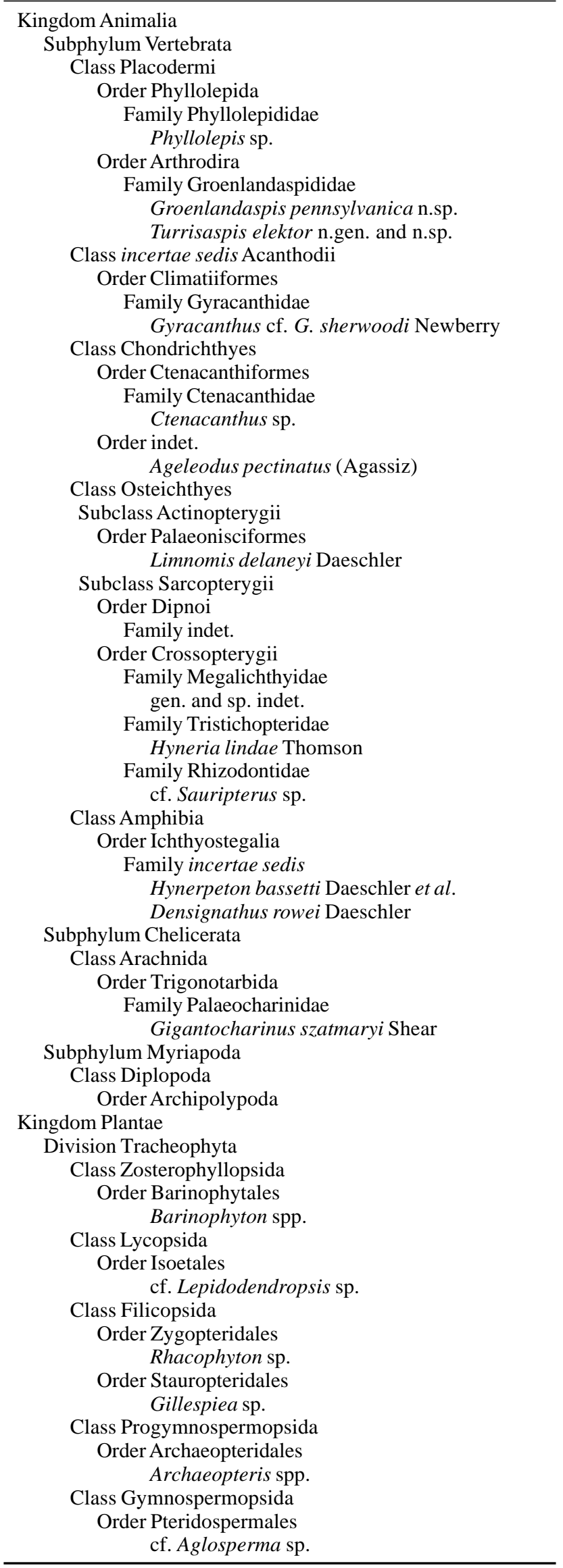

\& Villarroel (2000) report possible groenlandaspidid remains from the Frasnian of Columbia. Ritchie (1974, 1975), Young (1999), and others mention currently undescribed forms of Groenlandaspis from Frasnian and Famennian localities in New South Wales, Australia. Janvier et al. (1984) report Groenlandaspis from the ?Tournaisian of southeast Turkey. This paper describes two new taxa of Late Devonian (late Famennian) groenlandaspidids from non-marine beds at the Red Hill site in north-central Pennsylvania, USA. These are the first reported North American groenlandaspidids outside of Greenland and they reinforce the cosmopolitan distribution of the group in the Late Devonian.

The Red Hill fossil site is located in central Clinton County, Pennsylvania, USA (Fig. 1). The locality is a onekilometre-long road cut through the upper part of the Duncannon Member of the Catskill Formation. The Duncannon Member is approximately 250 meters thick in this part of north-central Pennsylvania and is regarded as non-marine in origin, the deposits of meandering fluvial systems on a broad alluvial plain (Berg et al., 1983; Sevon, 1985; Woodrow et al., 1995). The Red Hill road cut exposes a 30-meter section of the Duncannon Member and within that sequence the fossiliferous zone producing all of the vertebrate material in this report is about two meters thick (the fossiliferous zone is marked with asterisk in Fig. 1). Since 1993, the site has produced a diverse fauna and flora (Table 1), providing a snapshot of a Late Devonian freshwater / terrestrial assemblage.

The environments of deposition for the fossiliferous zone at Red Hill are interpreted as shallow channel margin facies and overbank pond facies (Daeschler \& Cressler, 1999). Groenlandaspidids are one of the most abundant macrovertebrates at the Red Hill site. The two taxa presented here occur together in all lithofacies within the fossiliferous zone. Although disarticulated groenlandaspidid material is common throughout the fossiliferous zone, one bedding plane within the channel margin facies contained an area of several square meters with abundant articulated, although crushed, remains. This layer preserves Turrisaspis elektor n.gen. and n.sp. of varied sizes in a density of approximately 20 individuals per square meter. The horizon also preserves articulated, although less abundant material of an unidentified acanthodian and Limnomis delaneyi, the only actinopterygian known from the Red Hill site (Daeschler, 2000b). This horizon may represent a mass mortality event within the channel margin facies, perhaps the result of stranding in an ephemeral pool as water levels fluctuated.

The Catskill Formation in Pennsylvania has a long history of vertebrate palaeontological studies prior to the recent work at Red Hill. In 1843, James Hall described a pectoral fin and scales of a large rhizodont sarcopterygian, Sauripterus taylori, from undifferentiated Catskill Formation in southern Tioga County. This fin has played prominently in discussions of the origin of the tetrapod limb, although no additional material of Sauripterus was found in the Catskill Formation until 1995 when another pectoral fin was found (Daeschler \& Shubin, 1998). The porolepiform sarcopterygian Holoptychius americanus Leidy, 1856 was described from the Catskill Formation in Tioga County and isolated scales of Holoptychius sp. are commonly encountered at most fossiliferous sites. Newberry (1889) described the phyllolepid placoderm, 
Phyllolepis delicatula, from the Catskill Formation near Leroy, Bradford County. This genus is also found at the Red Hill site and is presently under study. The antiarch placoderm Bothriolepis is the most common taxon found in the Catskill Formation. Bothriolepis nitida (Leidy, 1856) and Bothriolepis minor Newberry 1889 were each described from the Catskill Formation in Tioga County. Weems et al. (1981) described Bothriolepis virginiensis from Catskill equivalent strata in Virginia. Thomson \& Thomas (2001) and Young (1988, fig. 65H) provide illustrations of Bothriolepis material from the Catskill Formation in Pennsylvania. In the 1960s and 1970s Keith S. Thomson and students from Yale University collected at various sites in the Catskill Formation and described the large tristichopterid sarcopterygian, Hyneria lindae Thomson, 1968 and the megalichthyid sarcopterygian, Sterropterygion brandei Thomson, 1972 from Clinton and Lycoming Counties, respectively. Recent work has also reported on material of the acanthodian Gyracanthus sp. from Sullivan County (Sullivan et al., 1999). Recent palynomorph biostratigraphic studies of some fossil sites within the Catskill Formation in Clinton and Lycoming Counties indicate a Famennian age for the recently worked sites (Traverse, pers. comm.). Precise stratigraphic control for earlier sites is not available.

Red Hill in Clinton County has produced the unique faunal assemblage presented in Table 1. (Daeschler et al., 1994; Daeschler, 1998; Cressler, 1999; Daeschler, 2000a,b; Shear, 2000; Davis et al., 2001; Downs \& Daeschler, 2001). Red Hill is the only site in the Catskill Formation that has yielded groenlandaspidid material. The Red Hill fauna stands in sharp contrast to the more commonly encountered Bothriolepis and Holoptychius-dominated fauna of the Sherman Creek Member of the Catskill Formation. Neither Bothriolepis nor Holoptychius is found at Red Hill although Daeschler et al. (1994) erroneously listed Bothriolepis from the Red Hill site based on fragmentary, ornamented plates that have now been re-identified as groenlandaspidid. These distinct ichthyofaunas within the laterally-equivalent facies of the Catskill Formation represent different sedimentological and palaeoecological settings within the Catskill Delta complex (Daeschler, 1998).

Methods and materials. Most specimens were prepared mechanically with a sharpened carbide rod. A few specimens in which the bone was crushed or poorly preserved were placed in a 10 percent $\mathrm{HCl}$ solution for 24 to 48 hours to dissolve the bone and leave a detailed mold of the specimen in fine sandstone matrix. The acid-etched mold was covered with several thin layers of latex, allowed to dry thoroughly, and pulled off to obtain a latex peel. Most specimens and all latex peels were coated with ammonium chloride prior to imaging. All specimen images were captured digitally with a Kodak Digital Camera System 460.

Measurements were made on isolated elements and head shields that were complete enough to get accurate data using callipers. Height, length and width measurements were made following the methods illustrated in Figs. 10 and 12.

Abbreviations used in the text and figures are as follows. $\mathrm{ADL}$, anterior dorsolateral plate; $\mathrm{AL}$, anterior lateral plate; AMV, anterior median ventral plate; APi, anterior pineal plate; AVL, anterior ventrolateral plate; $\mathrm{Ce}$, central plate; IL, interolateral plate; M, marginal plate; MD, median
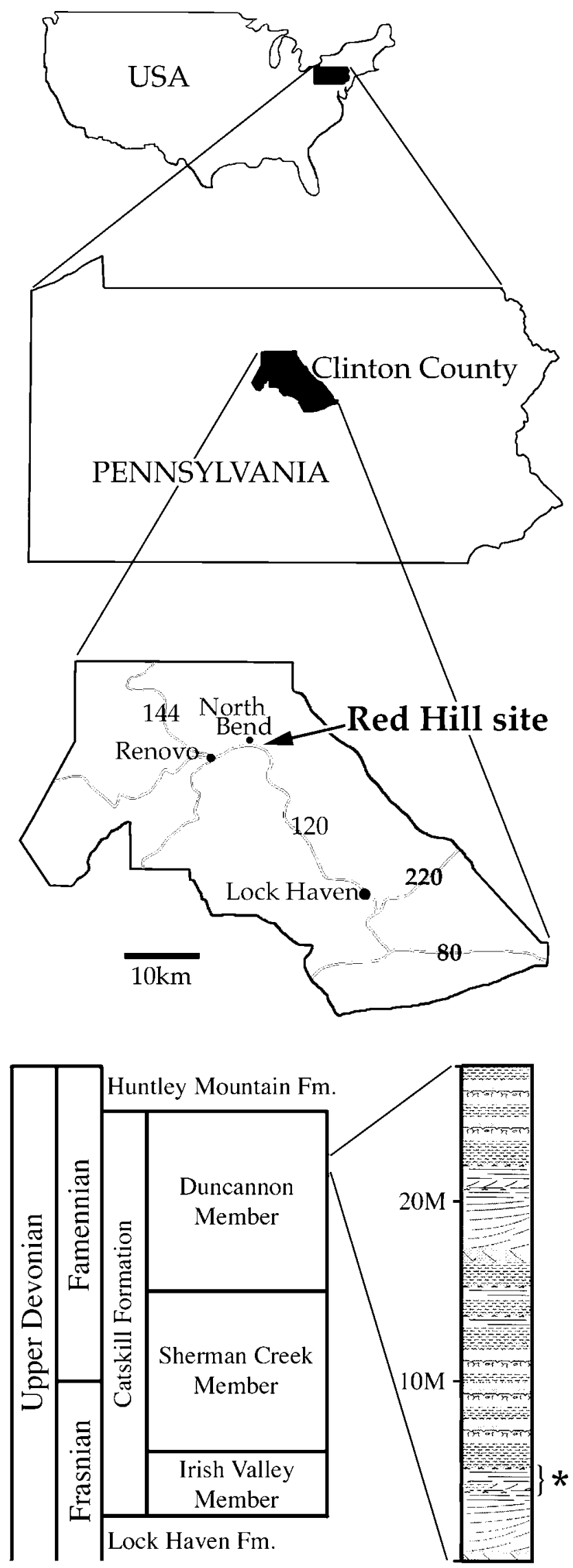

Red Hill section

Fig. 1. Location and stratigraphic framework of the Red Hill site, Clinton County, Pennsylvania, United States of America. Twometer-thick fossiliferous zone marked with an asterisk. 
dorsal plate; $\mathrm{Nu}$, nuchal plate; $\mathrm{PDL}$, posterior dorsolateral plate; Pi, pineal plate; PL, posterior lateral plate; PM, postmarginal plate; PMV, posterior median ventral plate; $\mathrm{PNu}$, paranuchal plate; $\mathrm{PPi}$, posterior pineal plate; $\mathrm{PrO}$, preorbital plate; Psp, parasphenoid; PtO, postorbital plate; PVL, posterior ventrolateral plate; R, rostral plate; Sgn, supragnathal; SP, spinal plate. Museum acronym: ANSP, The Academy of Natural Sciences of Philadelphia.

\section{Systematic palaeontology}

Class Placodermi McCoy, 1848

Order Arthrodira Woodward, 1891

Suborder Phlyctaenioidei Miles, 1973

Family Groenlandaspididae Obruchev, 1964

Genus Groenlandaspis Heintz, 1932

Type species. Groenlandaspis mirabilis Heintz 1932; Late Devonian, East Greenland.

\section{Groenlandaspis pennsylvanica n.sp.}

Figs. 2-4

Holotype (Fig. 2B). ANSP 20755, median dorsal plate (MD) in right lateral view and partially exposed in left lateral view. Complete except for missing tip of the anteroventral projection. Ventral margin slightly crushed.

Other material. All of the material of this species consists of isolated trunk plates: 9 ALs (3 complete and 6 partial); 1 ADL (complete); 10 PDLs (5 complete and 5 partial); 4 MDs (2 complete and 2 partial); 1 AVL (partial); 1 PVL (partial). Specimen catalogue numbers and the measurements of complete elements are listed in Appendix 1.

Locality and horizon. USA, Pennsylvania, Clinton County, Red Hill site, north side of Route $120,1 \mathrm{~km}$ east of the village of North Bend ( $\left.41^{\circ} 20.633^{\prime} \mathrm{N} 77^{\circ} 40.814^{\prime} \mathrm{W}\right)$ (Fig. 1). Catskill Formation, Duncannon Member.

Age. Late Devonian, late Famennian Stage (Fa2c substage); Grandispora cornata / Rugispora flexuosa palynomorph zone (Traverse, in press).

Etymology. Named for the State of Pennsylvania where this taxon was discovered and studied.

Diagnosis. The MD has a low profile (average $\mathrm{H} / \mathrm{L}=0.48$ ) with ornament of coarse tubercles along the anterodorsal margin and covering the lateral surface of the posteroventral region with the largest tubercles on the posterodorsal margin. Ornament of fine ridges on the MD radiate from apex to the ventral margin. The dorsal margin of the ADL is steeply inclined with a narrow anterodorsal overlap zone for the MD. The lateral surface of the PDL is ornamented with fine tubercles that form ridges radiating from the bend in the sensory canal.

Remarks. The specimens referred to G. pennsylvanica occur as isolated plates within the 2-meter-thick fossiliferous zone at Red Hill. Although no articulated trunk armour has been discovered, the material is believed to be from a single taxon because the elements "fit together" both in terms of size and the shapes of plate margins and overlap zones. When compared to other groenlandaspidid material from the same fossiliferous zone at Red Hill, the G. pennsylvanica specimens are significantly larger and the trunk shield shape is much lower and longer. There is no overlap in the size or shape characteristics of most trunk elements between the two groenlandaspidid taxa at Red Hill.

\section{Description}

ADL (anterior dorsolateral plate) (Figs. 2C, 4C). The ADL is known from a single specimen, ANSP 20743 (Fig. 2C), which is exposed in lateral view. This specimen is missing narrow parts of the caudal and ventral margins, although the natural mold of the overall shape of the element is preserved in the matrix. The dorsal and anteroventral margins are steeply inclined giving the entire element a tall, rhomboidal shape. It is difficult to quantify the shape of the ADL in a way that allows comparison to other taxa but for this paper we have derived a measure of the angle of the dorsal margin relative to the dorsolateral sensory canal on the ADL (see Fig. 2C'). On ANSP 20743, the angle formed by lines tracing the dorsal margin and the general trend of the dorsolateral sensory canal is $55^{\circ}$. The overlap zone for the median dorsal plate on the dorsal margin of the ADL is narrow along the anterodorsal margin and wider posteriorly. The ornament on the ADL consists of fine tubercles distributed evenly across the dermal surface. Height and length measurements for the single ADL are presented in Appendix 1.

PDL (posterior dorsolateral plate) (Figs. 2D,E; 4B). The PDL is known from ten specimens ( 5 complete and 5 partial). The overlap area for the MD reaches the caudal margin at the tip of a pronounced posterodorsal projection. The dorsolateral sensory canal comes to a rounded apex slightly caudal to the centre of the element where its path bends at $90^{\circ}$. The ornamentation on the lateral surface of the PDL consists of rows of fine tubercles radiating from the bend in the sensory canal toward the edges. The medial surface of the PDL (Fig. 2E) has a central, thickened zone extending from the centre of the ventral margin to the symphysial area where the left and right sides of the trunk shield met beneath the median dorsal plate. The angle formed by this symphysial surface and the body of the PDL is about $35^{\circ}$ suggesting that the two sides of the trunk diverged at an angle of $70^{\circ}$ from beneath the MD (Fig. 3). The height of the symphysial surface is about $30 \%$ of the total height of the PDL. Height and length measurements for the five complete PDL plates are presented in Appendix 1.

AL (anterior lateral plate) (Figs. 2F,G; 4D). The AL is known from nine specimens (4 complete and 5 partial). The shape is rhomboidal with the length about twice the height. The caudal margin is concave, and the cranial margin slopes to a point ventrally. The lateral surface has a raised crest that slopes upward from the anteroventral tip and bifurcates slightly cranial to the centre of the element, forming two raised crests that diverge toward the caudal margin (Fig. 2F). The ornamentation on the lateral surface consists of fine tubercles randomly distributed and fine ridges near the ventral margin. The medial surface is smooth with contours mimicking the lateral surface (Fig. 2G). Height and length measurements for the three complete AL 

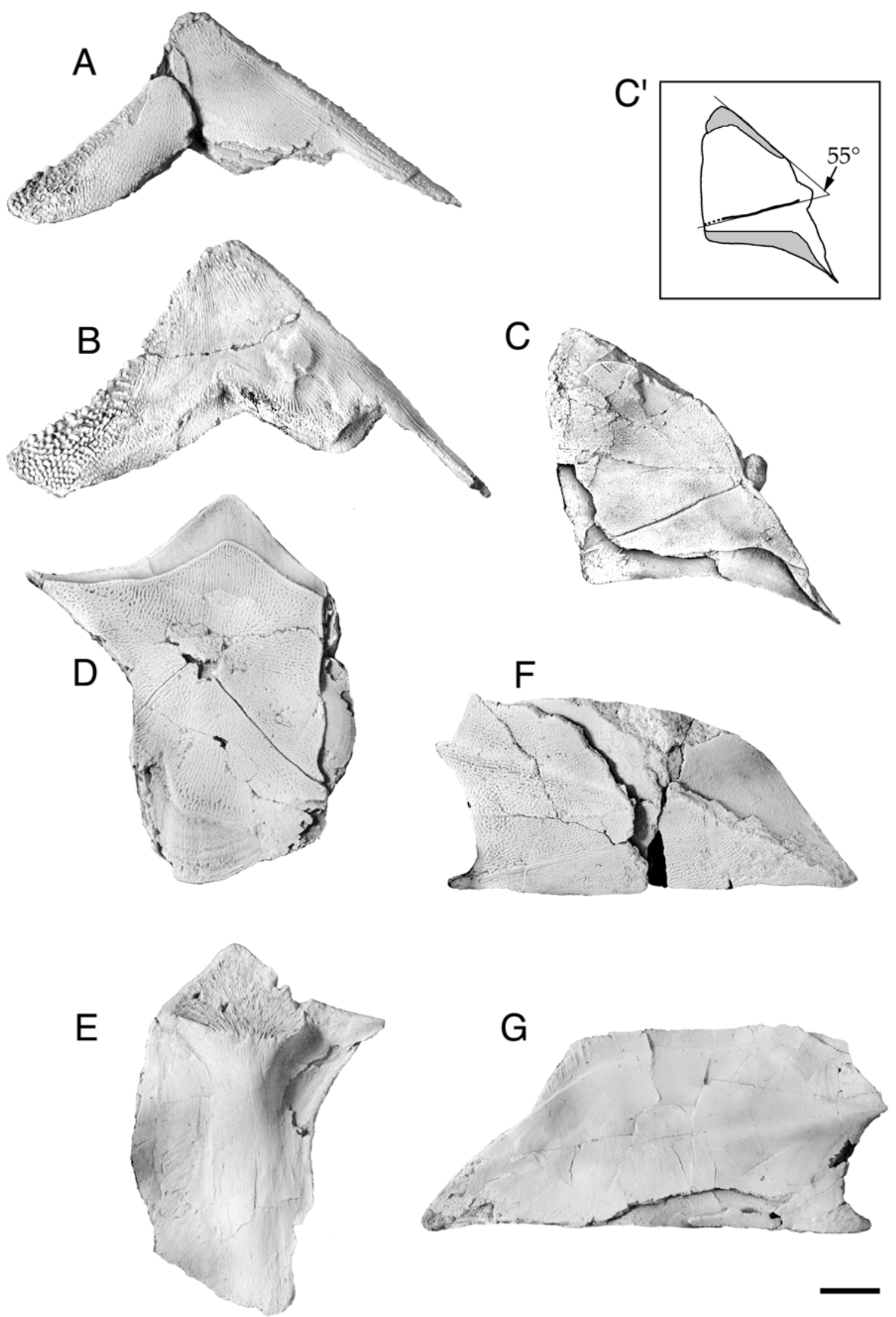

Fig. 2. Trunk plates of Groenlandaspis pennsylvanica. Median dorsal plates (MD): A, ANSP 20753; B, ANSP 20755. Anterior dorsolateral plate (ADL): $C$, ANSP 20743 lateral aspect; $C^{\prime}$, method for measuring the angle of the dorsal margin of the ADL. Posterior dorsolateral plates (PDL): $D$, ANSP 20725, lateral aspect; $E$, ANSP 20700, medial aspect. Anterior lateral plates (AL): $F$, ANSP 20940, lateral aspect; $G$, ANSP 20727, medial aspect. All specimens whitened with ammonium chloride. Scale bar $=1 \mathrm{~cm}$. 


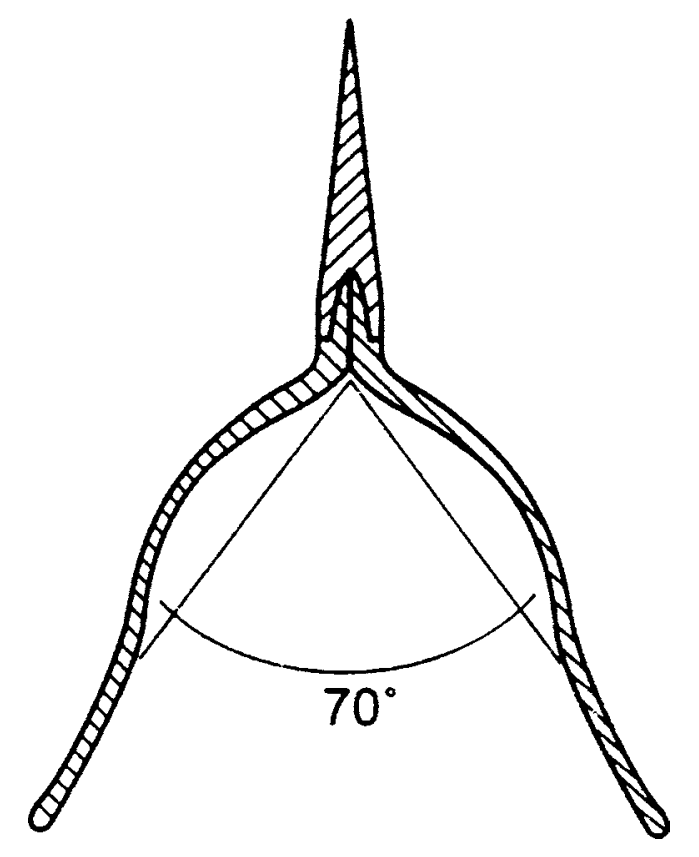

Fig. 3. Schematic cross-section of the dorsolateral and dorsal trunk shield of Groenlandaspis pennsylvanica determined by the angle of internal symphysis of the PDL.

plates are presented in Appendix 1.

MD (median dorsal plate) (Figs. 2A,B; 4A). The median dorsal plate of $G$. pennsylvanica is known from five specimens ( 3 complete and 2 partial). The general shape of the MD is long and low with a height to length ratio (using the measuring method shown in Fig. 10) of about 0.5. The blunt apex of the MD makes an $80^{\circ}$ to $90^{\circ}$ angle midway along the total length of the element. The anteroventral projection of the $\mathrm{MD}$, where it overlaps the $\mathrm{ADL}$, is long

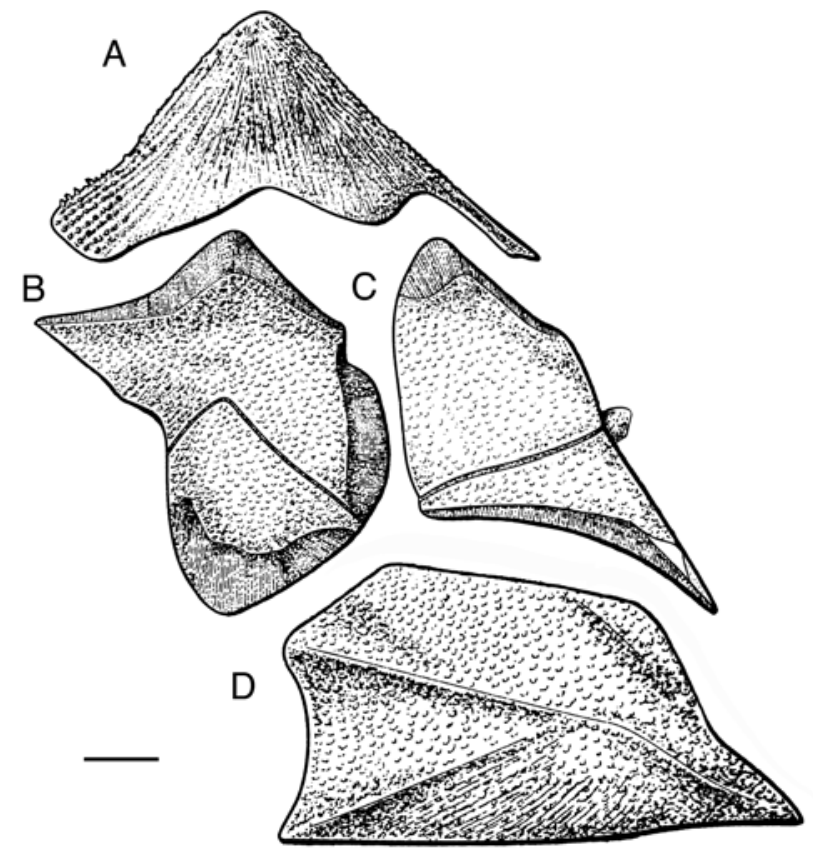

Fig. 4. Reconstructed lateral and median dorsal plates of Groenlandaspis pennsylvanica (PL not known). A, MD; $B$, PDL; $C$, ADL; $D$, AL. Scale bar $=1 \mathrm{~cm}$. and narrow. Ornamentation of coarse tubercles is found along the anterodorsal margin and covers the posteroventral area of the element, with the largest elements of ornament along the posterodorsal margin. Ornamentation of fine striations radiating from the apex to the ventral margin covers the rest of the MD. Height and length measurements for the 3 complete MD plates are presented in Appendix 1.

Ventral Trunk. It is worth mentioning two incomplete ventral trunk elements here because they are the only examples of such material encountered. These specimens are judged to belong to G. pennsylvanica because they are significantly larger and morphologically distinct from material described later in this paper as Turrisaspis elektor. ANSP 21324 is a partial left AVL (anterior ventrolateral plate) with a length of at least $60 \mathrm{~mm}$ and a width of $38 \mathrm{~mm}$. The dermal surface is smooth except for a few scattered small tubercles near the centre of the plate, fine ridges along the posterolateral margin, and finely-reticulate ornament in the V-shaped depression in the posterolateral quadrant. ANSP 21288 is a partial right PVL (posterior ventrolateral plate) with a total length of at least $53 \mathrm{~mm}$ and a width of at least $42 \mathrm{~mm}$. Along the posterior half of the medial margin is a distinct overlap zone for the left PVL. Ornamentation of tubercles is well developed posteriorly, with the largest tubercles along the ridge where the lateral flange of the PVL angles dorsally. The tubercular ornament thins anteriorly to a smooth surface with only scattered tubercles. The aforementioned specimens, ANSP 21324 (AVL) and ANSP 21288 (PVL), occur in close proximity $(3 \mathrm{~mm})$ to one another on the same matrix block, but their association is uncertain.

\section{Comparison to other species of Groenlandaspis}

The elements of the trunk shield of Groenlandaspis pennsylvanica (Figs. 2, 4) are similar to those of the welldocumented taxon Groenlandaspis antarctica (Ritchie, 1975, fig. 2; Denison, 1978, fig. 44A-C). There are, however, some morphological features of Groenlandaspis pennsylvanica that justify its status as a distinct species. The ADL of Groenlandaspis pennsylvanica has a more narrow and tall shape with a steeper dorsal margin than Groenlandaspis antarctica. The angle of the dorsal margin of Groenlandaspis antarctica, measured from published illustrations with the method shown in Fig. $2 \mathrm{C}^{\prime}$, is $42^{\circ}$, as opposed to $55^{\circ}$ in Groenlandaspis pennsylvanica. This comparison is only tentative because of very limited sample size $(n=1)$ for each taxon. The ornament on the lateral trunk elements of Groenlandaspis pennsylvanica consists of fine tubercles that are evenly distributed or in some areas, particularly the PDL, arranged in rows, forming fine ridges. The MD of Groenlandaspis pennsylvanica has the same general shape as Groenlandaspis antarctica but details of the ornament such as fine ridges radiating from the apex, and a narrow anteroventral projection, are distinct. Aside from the morphological differences, the early Frasnian age and Gondwanan occurrence of Groenlandaspis antarctica also suggest that the two taxa are not conspecific.

Comparisons to the Late Devonian Euramerican forms G. disjectus and G. mirabilis are confounded by the incomplete nature of those taxa. The PDL is known from many groenlandaspidids, however, and can provide informative comparisons among most of the groenlandaspidid taxa. Figure 5 provides a comparison of the size 
and shape of groenlandaspidid PDLs re-drawn from published accounts. As mentioned above, the PDL of $G$. pennsylvanica is very similar in shape to $G$. antarctica (Fig. 5B), but distinctive ornament characterizes each. The PDL of G. disjectus (Fig. 5C) and G. mirabilis (Fig. 5D) have different shapes than G. pennsylvanica (Fig. 5A), particularly in the dorsal margin and posterodorsal projection. The PDLs of other groenlandaspidid taxa (Fig. $5 \mathrm{E}-\mathrm{J})$ are very different in shape from $G$. pennsylvanica. Such a comparison does not illustrate the variation found within any of the taxa.

Groenlandaspis pennsylvanica is rare at the Red Hill site, known only from the aforementioned 27 isolated trunk plates. Smaller groenlandaspidid material with morphologies distinct from G. pennsylvanica is found in the same 2meter-thick fossiliferous zone and is much more abundant. This smaller material is described below from 81 complete isolated trunk plates, 10 measurable head shields, and five partially articulated ventral trunk shields.

\section{Turrisaspis n.gen.}

Type species. Turrisaspis elektor n.sp., monotypic.

Etymology. From the Latin for spire, "turris", and Greek for shield, "aspis".

Diagnosis. As for species, by monotypy.

\section{Turrisaspis elektor n.sp.}

Figs. 6-9, 11

Holotype (Fig. 6). ANSP 20961 A, articulated specimen on matrix block with right lateral view of trunk shield and dorsolateral view of head shield (Fig. 6A). The counterpart (ANSP 20961B) was etched in $10 \%$ hydrochloric acid to make a clean external mold of the specimen. Figure $6 \mathrm{~B}$ is a whitened latex peel of the counterpart block. The counterpart lacks areas with impressions of the AL and SP. Figure 6C is a labelled drawing of ANSP 20961A/B showing plate boundaries and sensory canals.

Other material. Turrisaspis elektor is known from the following 81 isolated, measurable elements: MD, 29; PDL, 5; ADL, 7; AL, 11; PL, 6; AVL, 12; PMV, 7; PVL, 1; SP, 3. Additionally there are 10 measurable head shields and 5 articulated ventral trunk shields. See Figs. 10 and 12 for methods used to take measurements and Appendix 2 for specimen catalogue numbers and measurements.

Locality and horizon. USA, Pennsylvania, Clinton County, Red Hill site, north side of Route $120,1 \mathrm{~km}$ east of the village of North Bend (41 $\left.{ }^{\circ} 20.633^{\prime} \mathrm{N} 77^{\circ} 40.814^{\prime} \mathrm{W}\right)$ (Fig. 1). Catskill Formation, Duncannon Member.

Age. Late Devonian, late Famennian Stage (Fa2c substage); Grandispora cornata / Rugispora flexuosa palynomorph zone (Traverse, in press).

Etymology. Named for the truest friend of a supporter of our research.

Diagnosis. A small groenlandaspidid with a short head shield and tall and narrow dorsal trunk elements. The head shield is almost as wide as long (average W/L equals 0.96). The pineal is divided into two distinct plates in every specimen and the postmarginal makes contact with the postorbital plate, excluding the marginal plate from the lateral margin of the head shield. A continuation of the supraorbital sensory line reaches the caudal margin of the paranuchal plate. The PDL has an average H/L ratio of 2.42 . The posterodorsal projection of the PDL is short and angled sharply upward so that the overlap zone for the MD does not reach the caudal margin of the element. The height of the symphysial area on the visceral surface of the PDL is $40 \%$ of the total height of the element. The MD is also high and narrow and approximately equal in height to the PDL.
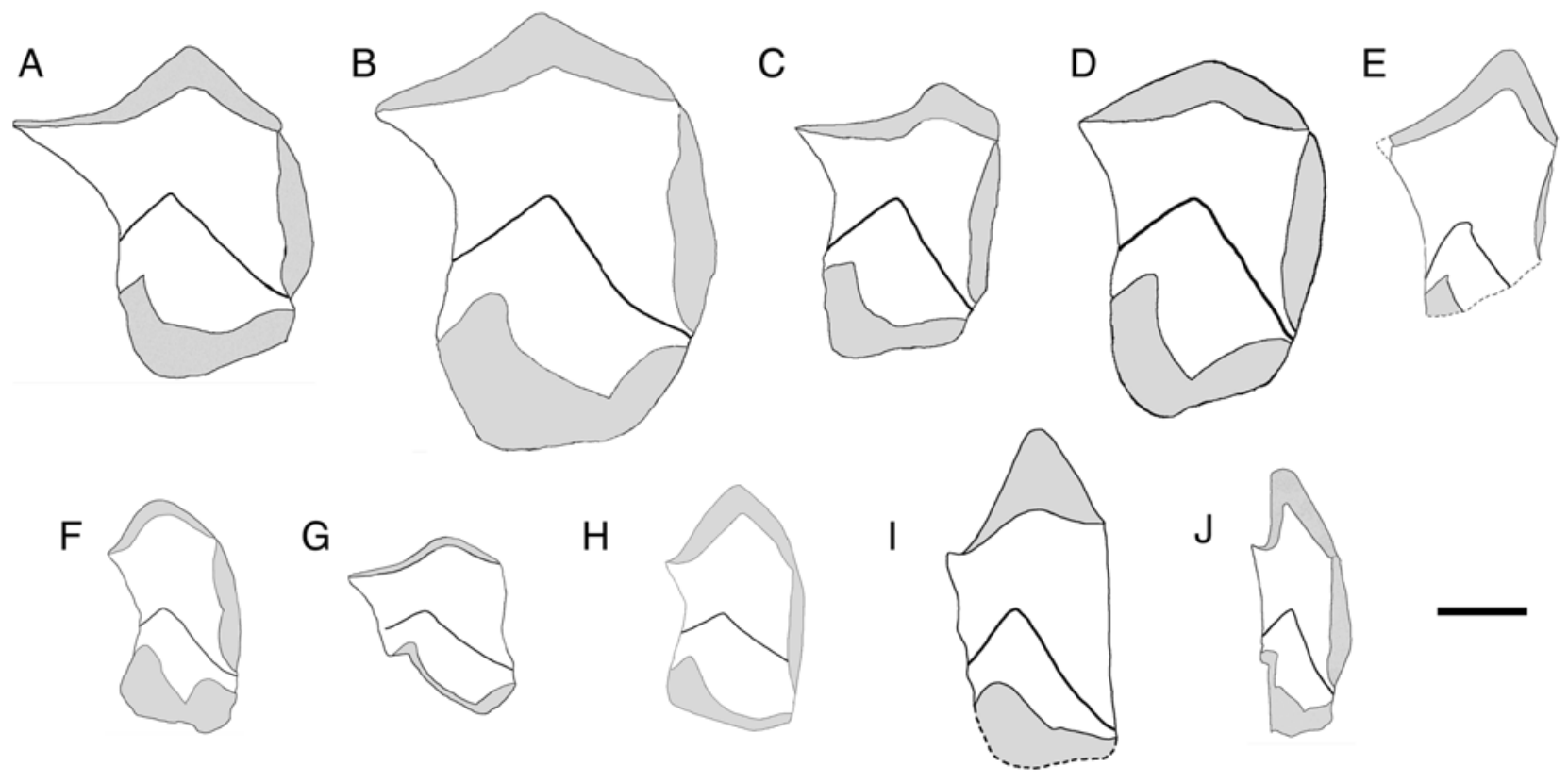

Fig. 5. Comparison of posterior dorsolateral plates (PDL) from groenlandaspidids. A, Groenlandaspis pennsylvanica n.sp.; B, G. antarctica; C, G. disjectus; D, G. mirabilis; E, G. seni; F, G. riniensis; G, Boomeraspis goujeti; H, Tiaraspis subtilis; I, Africanaspis doryssa; J, Turrisaspis elektor n.gen. and n.sp. Scale bar $=2 \mathrm{~cm}$. 
The MD has numerous coarse serrations along the caudal margin and tubercles on the lateral surfaces that form rows parallel to the ventral margin.

\section{Description}

Head Shield (Figs. 6-8, 11F). The pattern of sensory lines and bones in the head shield of Turrisaspis elektor is similar to other Late Devonian groenlandaspidids in which head shields are known (Tiaraspis, $G$. riniensis, and $G$. antarctica). The supraorbital sensory line begins in the centre of the rostral margin of each preorbital plate and terminates within the central plate. Unreported from other taxa, the supraorbital sensory line on some Turrisaspis specimens, including the holotype, re-appears just caudal to the middle of the central plate and continue across the paranuchal plate to the caudal margin of paranuchal where it terminates near the end of the main lateral line. The infraorbital sensory line starts where the orbit meets the postorbital plate and divides in the centre of the postorbital plate. The central sensory line, the medial branch of the infraorbital sensory line, extends onto the central plate and terminates there. The main lateral line, the lateral branch of the infraorbital sensory line, terminates at the caudal margin of the paranuchal plate.

ANSP 20705 (Fig. 7) preserves the head shield in

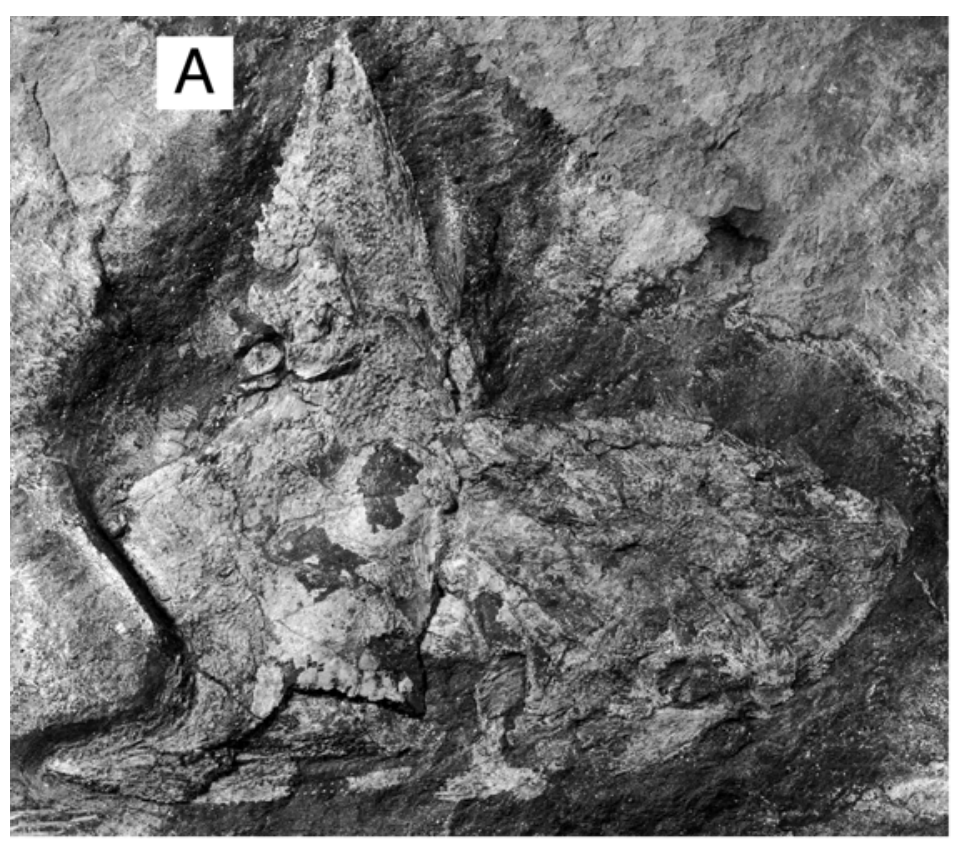
3-dimensions with parts of the lateral (AL) and ventral trunk shield (IL, AMV, AVL, and partial SP). The head shield of Turrisaspis elektor has a pineal plate that is divided into two separate elements, a character also seen in some undescribed Australian forms (A. Ritchie, pers. comm.). The APi is roughly square and has a distinct indentation in the centre of the visceral surface (see Fig. 8A,B). A similar indentation is seen on the $\mathrm{Pi}$ of Groenlandaspis disjectus (Ritchie, 1974) and Tiaraspis subtilis (Schultze, 1984). The PPi of Turrisaspis elektor is roughly triangular in ANSP 20705, but it is smaller and approaching oval-shaped in other specimens.

The relative size and shape of the two pineal elements is variable among the sample of

Turrisaspis head shields but two pineal B elements are present in every specimen examined. Schultze (1984) illustrates a small single pineal in Tiaraspis subtilis and a space not covered by bone between the pineal and the rostral. It seems possible
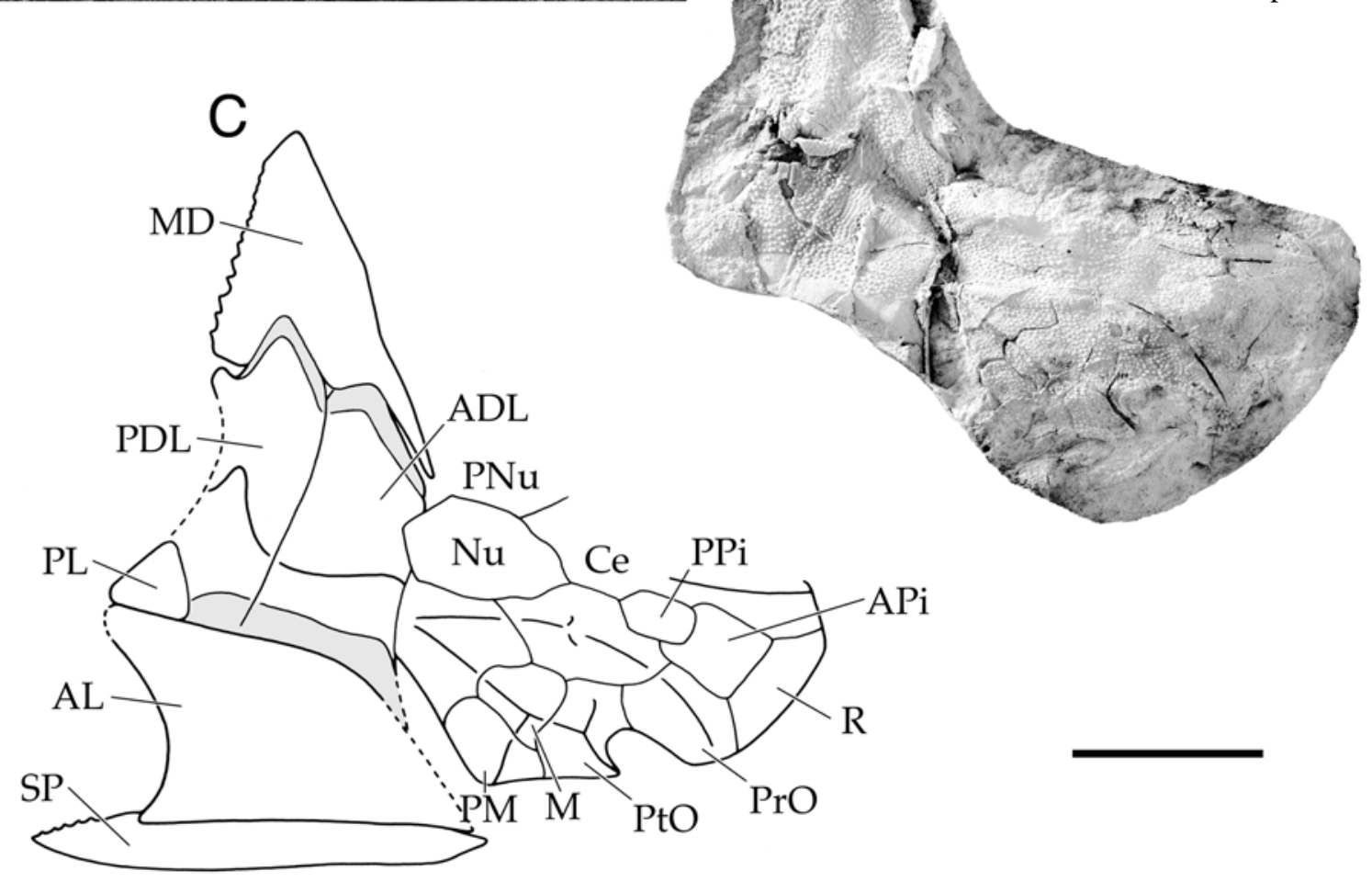

Fig. 6. Turrisaspis elektor, holotype, ANSP 20961, articulated specimen in right lateral view (head shield in dorsolateral view). A, specimen on matrix block; $B$, whitened latex peel made from counterpart block; $C$, line drawing of specimen using part and counterpart. Scale bar $=2 \mathrm{~cm}$. 

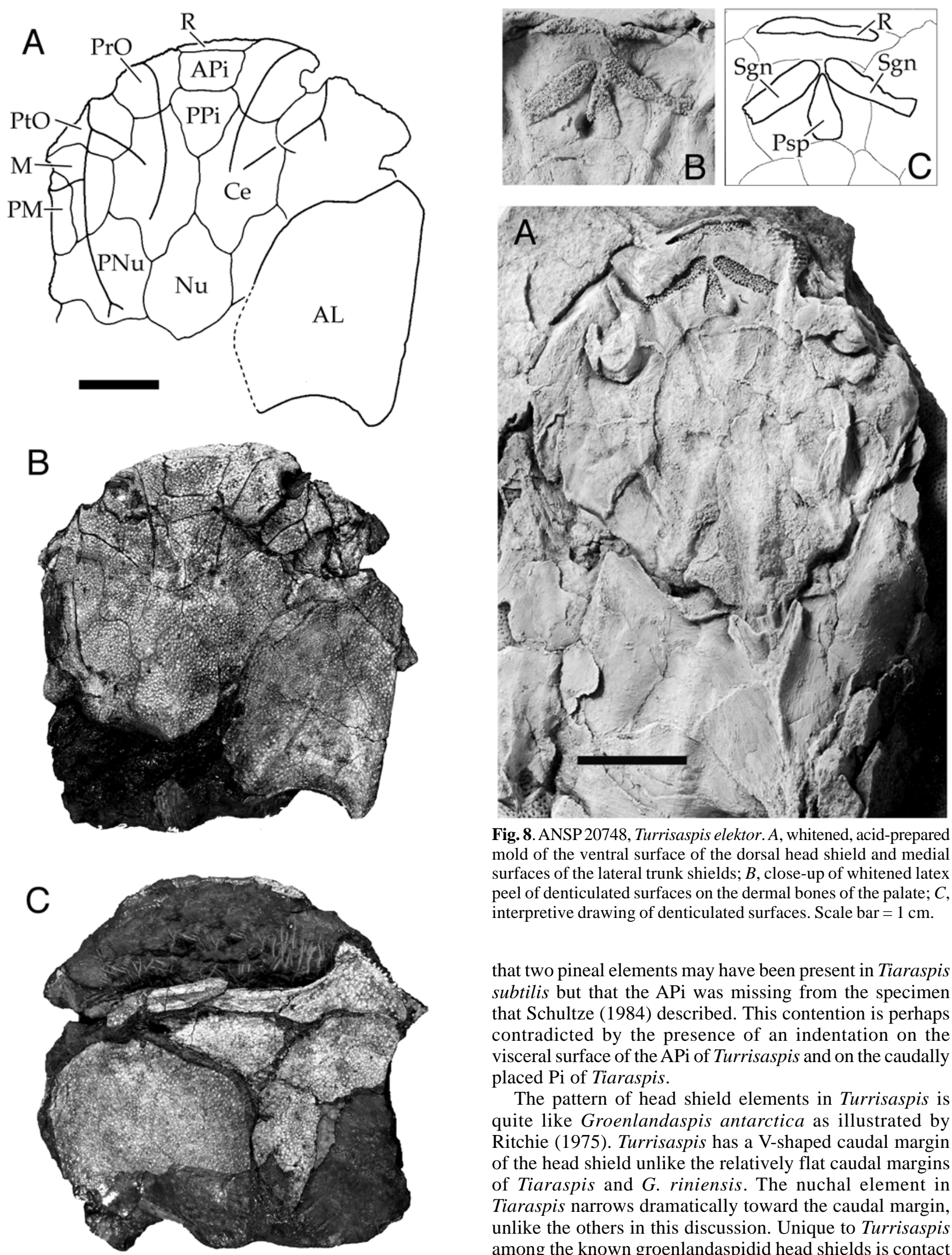

Fig. 8. ANSP 20748, Turrisaspis elektor. A, whitened, acid-prepared mold of the ventral surface of the dorsal head shield and medial surfaces of the lateral trunk shields; $B$, close-up of whitened latex peel of denticulated surfaces on the dermal bones of the palate; $C$, interpretive drawing of denticulated surfaces. Scale bar $=1 \mathrm{~cm}$.

that two pineal elements may have been present in Tiaraspis subtilis but that the APi was missing from the specimen that Schultze (1984) described. This contention is perhaps contradicted by the presence of an indentation on the visceral surface of the APi of Turrisaspis and on the caudally placed Pi of Tiaraspis.

The pattern of head shield elements in Turrisaspis is quite like Groenlandaspis antarctica as illustrated by Ritchie (1975). Turrisaspis has a V-shaped caudal margin of the head shield unlike the relatively flat caudal margins of Tiaraspis and G. riniensis. The nuchal element in Tiaraspis narrows dramatically toward the caudal margin, unlike the others in this discussion. Unique to Turrisaspis among the known groenlandaspidid head shields is contact between the postmarginal and postorbital plates, excluding

Fig. 7. Turrisaspis elektor, ANSP 20705. A, line drawing of head shield in dorsal view; $B$, dorsal view of head shield and anterior lateral plate; $C$, ventral view of head and partial trunk shield. Scale bar $=1 \mathrm{~cm}$. the marginal plate from the lateral margin of the head shield. In ANSP 20705 (Fig. 7) the marginal plate appears to reach the lateral margin on the left side of the head shield 
but that is an artifact of crushing in that area. Ornamentation of evenly-spaced tubercles cover the entire head shield of Turrisaspis elektor.

Two specimens that were prepared by acid etching show details of the feeding apparatus on the dermal bones of the palate and rostrum. ANSP 20748 (Fig. 8A) includes a mold of the palatal surface showing four elongate, denticulated surfaces (Fig. 8A,B). The raised surface in the centre of the palatal area is interpreted as the ventral surface of the parasphenoid and the surfaces on either side of the parasphenoid are interpreted as supragnathals. The crescentshaped, denticulated surface on the anterior-most margin of the mouth is interpreted as the anteroventral margin of the rostral plate (Fig. 8C). ANSP 21137 (not figured) shows the same morphology of feeding apparatus, although the denticulated surface on the ventral surface of the parasphenoid is broader.

Appendix 2 provides numerical data for the 10 measurable head shields of Turrisaspis elektor in the Red Hill sample. The specimens are usually flattened and thus distorted to varying degrees. The head shields in this sample show a range of lengths from 2.2 to $4.7 \mathrm{~cm}$ (measured from the anterior-most point on the rostral plate to the caudal-most point on the nuchal). The width of the head shields range from 2.2 to $4.3 \mathrm{~cm}$ (measured between the lateral-most points of the postmarginal plates). The head shield of Turrisaspis is almost as wide as long (average W/ L equals 0.96). Other groenlandaspidid head shields (known from Tiaraspis, G. riniensis, and G. antarctica) have relatively longer skulls, but no statistical comparisons were done for this study.

\section{Lateral Trunk Shield}

ADL (Figs. 9G-I, 11C). The ADL of Turrisaspis elektor has a rhomboidal shape. The sample of seven measurable ADLs (listed in Appendix 2) shows variation in size and proportions of this element. The height of the ADL plates varies from 1.5 to $3.8 \mathrm{~cm}$, and the average height/length ratio is 1.95 (measured as shown in Fig. 12). The dorsal and anteroventral margins are steep and the anteroventral and posterodorsal corners form acute angles. The anterodorsal margin of the ADL forms an angle of between $50^{\circ}$ and $60^{\circ}$ with the sensory canal. The caudal margin is concave where it overlaps the PDL. The ornamentation on the lateral surface consists of evenly distributed tubercles. There is a raised crest running from the condyle to the centre of the caudal margin (see Fig. 11C). This character is used by Long et al. (1997) to separate Africanaspis from Tiaraspis. A comparison of these high-spired taxa with Turrisaspis is presented below.

PDL (Figs. 9E,F; 11B). The PDL is tall and narrow, with an average height/length of 2.42 . The sample of five measurable PDLs is listed in Appendix 2. The caudal margin of the PDL does not have the pronounced posterodorsal projection seen in the genus Groenlandaspis (Fig. 5). Instead, the caudal margin of the Turrisaspis PDL angles sharply upward at the posterodorsal corner of the element, creating a relatively vertical caudal margin and excluding the overlap zone of the MD from reaching the caudal margin. The posterior and anterior segments of the dorsolateral canal meet at an angle of $70^{\circ}$. Ornamentation of small tubercles are evenly distributed on the dermal surface of the element. In visceral view there is a tall, narrow symphysial area in the dorsal region of the PDL. The angle formed by this symphysial surface and the body of the PDL is about $30^{\circ}$, suggesting that the two sides of the trunk diverged at an angle of $60^{\circ}$ from beneath the MD. The height of the symphysial surface is $40 \%$ of the height of the entire PDL.

AL (Figs. 9L-N, 11E). All specimens of the anterior lateral plate are longer than they are high. The sample of 11 measurable ALs is listed in Appendix 2. Height to length ratios vary from 0.55 to 0.83 , with the higher ratios occurring in the smaller individuals such as ANSP 20947 (Fig. 9L). Shape change of the AL during ontogeny may indicate a change in the angle of the head shield relative to the trunk. The caudal margin is concave, and the cranial margin slopes steeply to a ventral point. The dermal surface has a raised crest that slopes upward from the anteroventral tip and changes angle cranial to the centre of the element, continuing to the posterodorsal corner of the element. The ornamentation on the dermal surface consists of tubercles that are evenly distributed or sometimes arranged in roughly concentric rows.

PL (Figs. 9J,K; 11D). The PL of Turrisaspis elektor is a small, triangular element with a large overlap zone ventrally for the dorsal lamina of the PVL and the AL. On the visceral surface there is a pronounced thickened rim along the ventral margin. The sample of seven measurable PLs is listed in Appendix 2. The ornament on the lateral surface consists of tubercles and crests.

MD (Figs. 9A-D, 11A). The MD of Turrisaspis elektor is high and narrow when compared to the genus Groenlandaspis. The apex of the MD makes an angle of $30^{\circ}$ to $40^{\circ}$. Numerous coarse serrations line the caudal margin. The caudal margin of the MD is nearly vertical and sometimes actually slopes back so that the apex of the MD is the most posterior part of the element (Fig. 9D). In specimens with associated trunk shield elements, the height of the MD is roughly equal to the height of the PDL. The ornamentation on the MD consists of tubercles that are evenly distributed across most of the element or arranged in sinuous rows that are roughly parallel to the ventral margin.

The large sample size of MDs from Turrisaspis elektor (29 measurable specimens listed in Appendix 2) exhibits variation in size and shape. The large sample size provides an opportunity to confirm continuous variation within the sample and to examine intraspecific variation and ontogenetic change in this taxon. Figure 10 plots the height and length for the sample of measurable median dorsal plates of Turrisaspis elektor from Red Hill. Height was measured as the distance from the ventral margin of the MD (at the apex of the notch for the PDL) to the apex of the element. Length of the MD was measured perpendicular to the height measurement at the level of the apex of the notch for the PDL (see inset of Fig. 10). The distribution of points in Fig. 10 suggests that the size variation is continuous, arguing against an interpretation of more than one taxon within the sample, based on size. The variation around the best-fit line in Fig. 10 illustrates intraspecific and ontogenic variation in the shape of the MD, as captured by the simple 


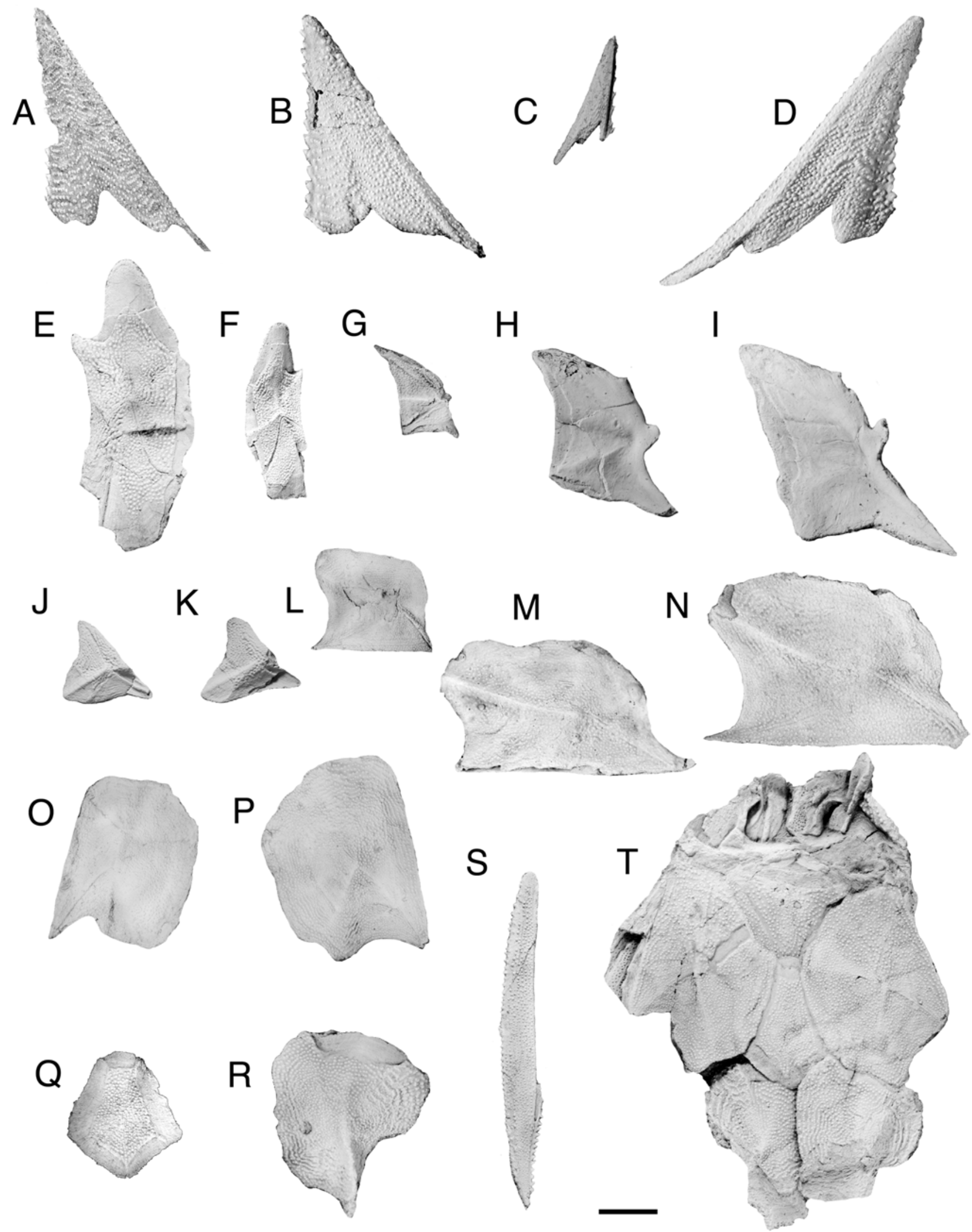

Fig. 9. Trunk plates of Turrisaspis elektor. Median dorsal plates (MD): A, ANSP 20687; B, ANSP 20714; C, ANSP $20707 ; D$, ANSP 20703. Posterior dorsolateral plates (PDL): $E$, ANSP 20742, lateral aspect; $F$, ANSP 20741, lateral aspect. Anterior dorsolateral plates (ADL): $G$, ANSP 20946, lateral aspect; $H$, ANSP 20766, medial aspect; $I$, ANSP 20754, medial aspect. Posterior lateral plates (PL): $J$, ANSP 20952, lateral aspect; $K$, ANSP 20953, lateral aspect. Anterior lateral plates (AL): $L$, ANSP 20947, lateral aspect; $M$, ANSP 20726, lateral aspect; $N$, ANSP 21328, lateral aspect. Anterior ventrolateral plates (AVL): $O$, ANSP 20768, ventral aspect; $P$, ANSP 20681, ventral aspect. Posterior median ventral plate (PMV): $Q$, ANSP 20695, ventral aspect. Posterior ventrolateral plate (PVL): $R$, ANSP 20684, ventral aspect. Spinal plate (SP): $S$, ANSP 20770. Articulated ventral trunk shield: $T$, ANSP 20688A. All specimens whitened with ammonium chloride. Scale bar $=1 \mathrm{~cm}$. 

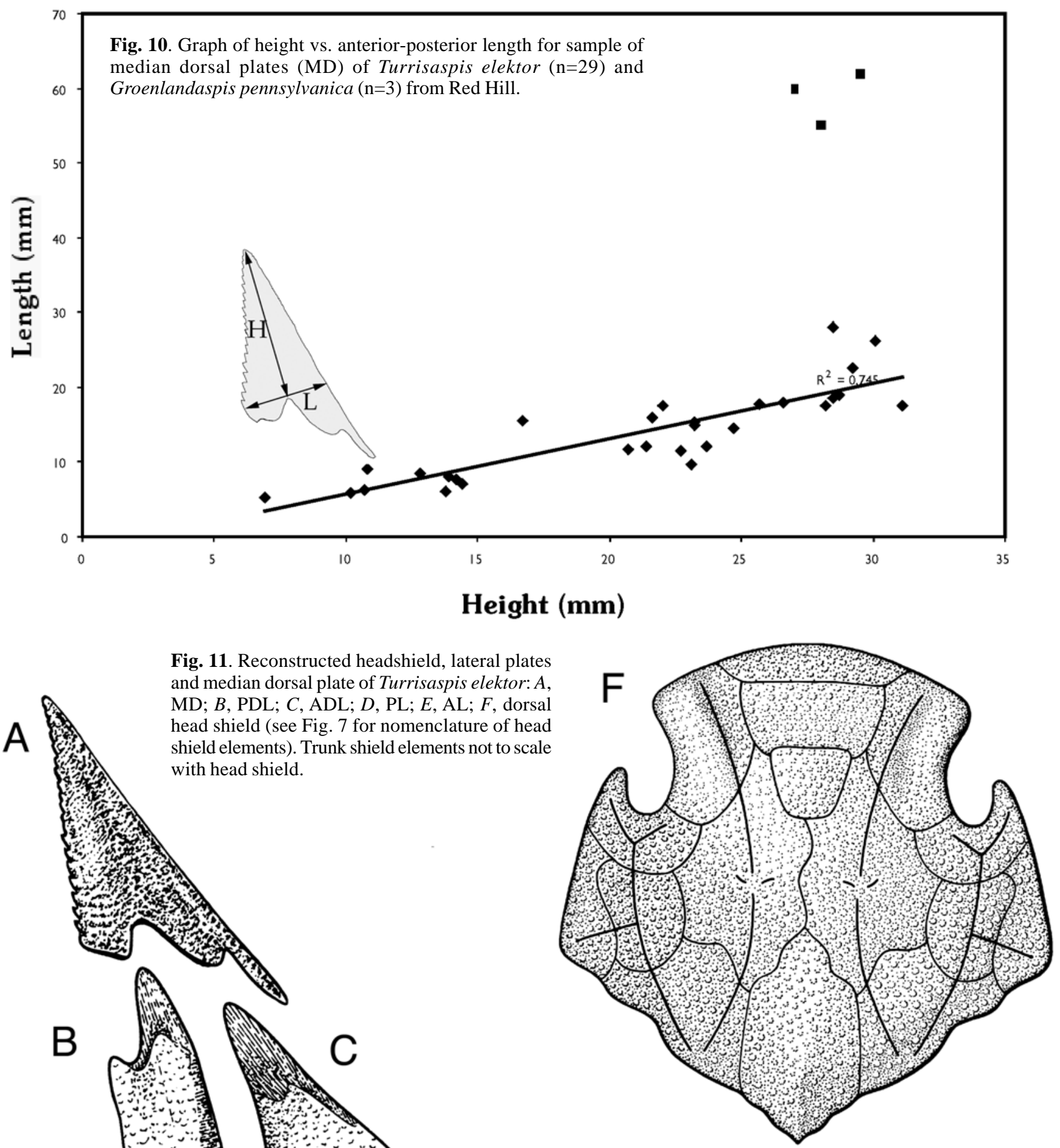

Fig. 11. Reconstructed headshield, lateral plates and median dorsal plate of Turrisaspis elektor: $A$, with head shield.

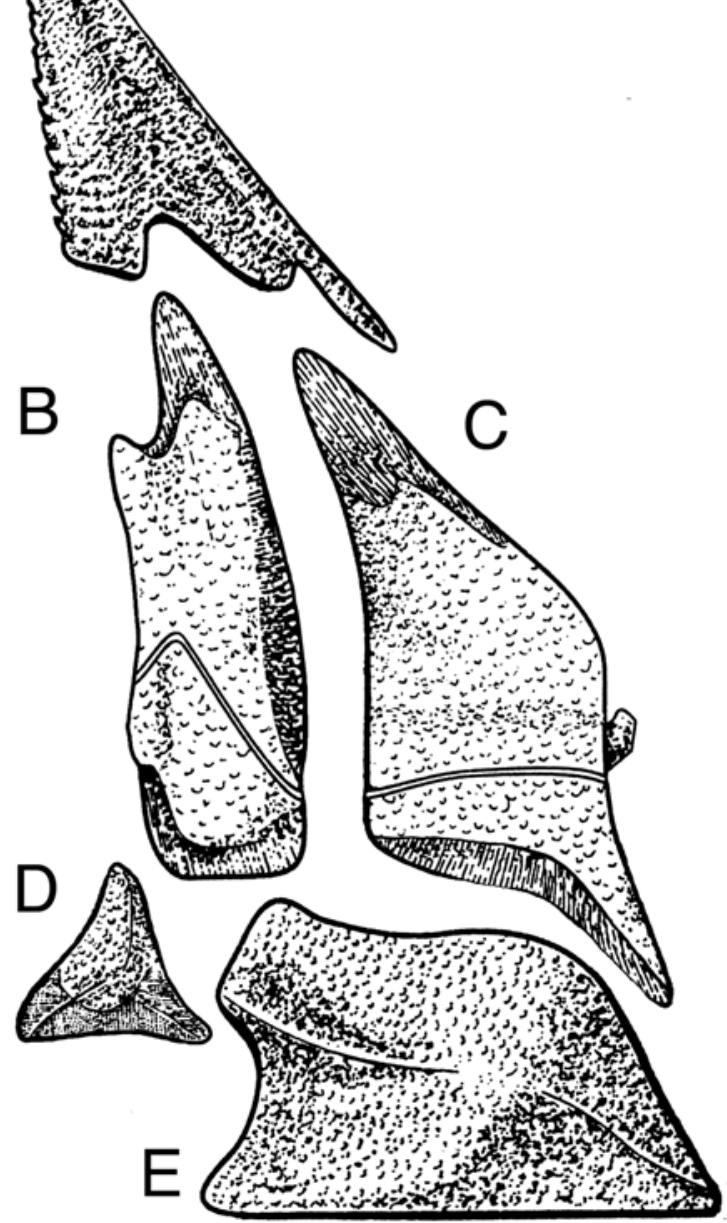

height and length measurements described above. Individual variation is also evident in the MD sample with respect to details of the serrations along the caudal margin, the development of ornament, and the slopes of the caudal and cranial margins (see Fig. 9A-D). Figure 10 also plots the three measurable specimens of the MD of Groenlandaspis pennsylvanicus. The distribution of these points clearly falls outside the range of variation in Turrisaspis.

Ventral Trunk Shield (Fig. 9T). The ventral trunk shield of Turrisaspis elektor is known from five articulated specimens and 23 measurable isolated elements. ANSP 20688A (Fig. 9T) is a well preserved example of an articulated ventral trunk shield. The pattern and relative proportions of the elements are like the ventral trunk shield of Groenlandaspis antarctica (Ritchie, 1975, fig. 2b), 

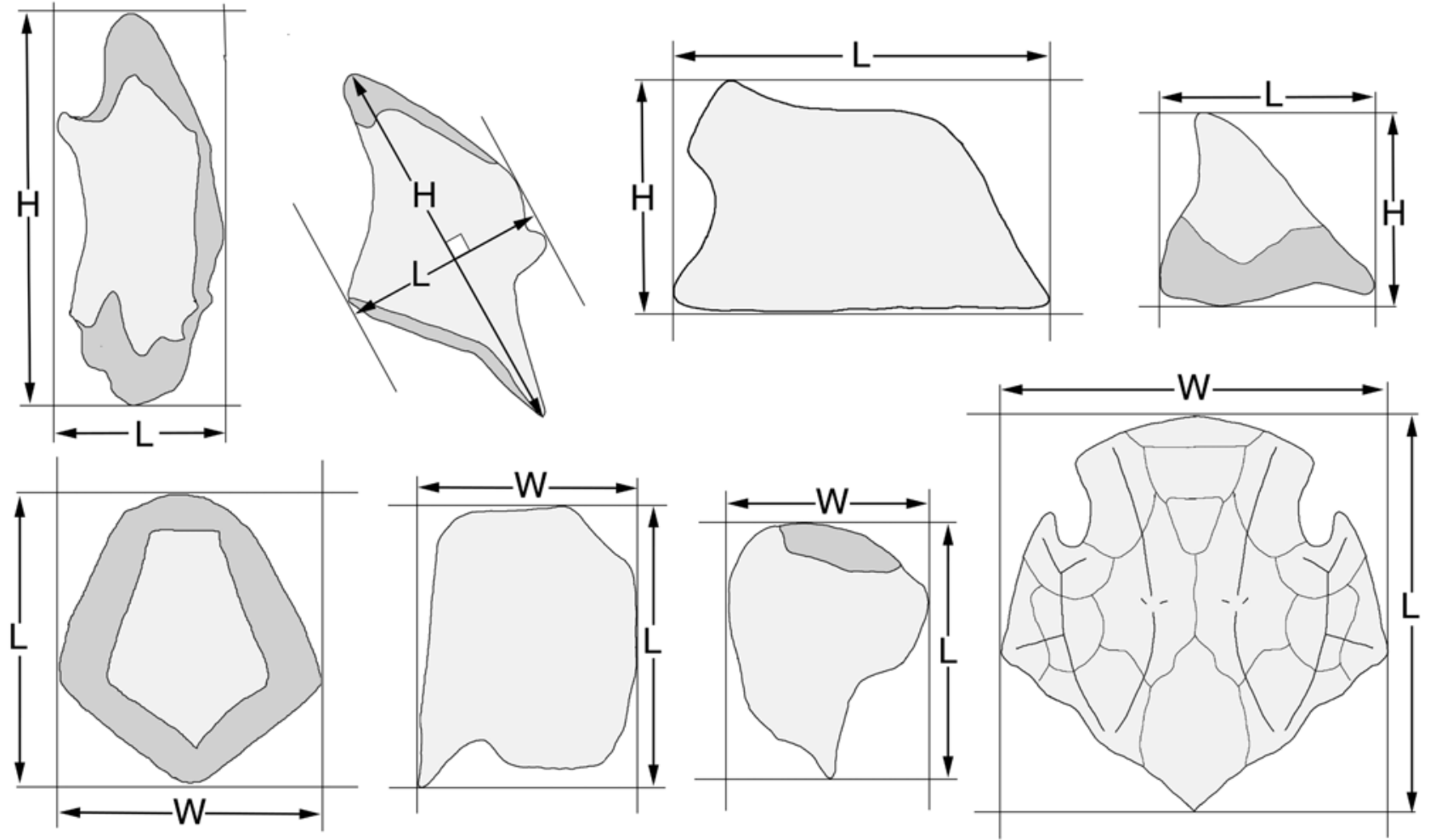

Fig. 12. Methods for deriving measurements of isolated trunk elements and head shields presented in Appendix 1 and 2.

although Turrisaspis elektor is significantly smaller.

AVL (Fig. 9 O,P). The AVL of Turrisaspis elektor is represented by 12 isolated specimens (list and measurements in Appendix 2 ). Within the sample of AVLs there is variation in the proportions of the element (width to length ratio varies from 0.62 to 1.0 ). The AVL has a straight lateral margin and a Vshaped depression that opens to the caudal margin. Ornamentation of fine tubercles are evenly distributed or arranged in rows following the margins of the plate.

PMV (Fig. 9Q). The PMV of Turrisaspis elektor is represented by seven isolated specimens (list and measurements in Appendix 2). The PMV is coffin-shaped, with a wide margin where it is overlapped from all sides. The PMV is ornamented with fine tubercles on the dermal surface.

PVL (Fig. 9R). The PVL of Turrisaspis elektor is represented by one isolated specimen (list and measurement in Appendix 2). On the cranial margin there is a distinct, crescent-shaped overlap area where the AVL overlaps the PVL. It appears that the left PVL overlaps the right PVL along part of the midline, although no isolated right PVL was present to observe the nature of the overlap area. The lateral flange of the PVL is angled at about $130^{\circ}$ relative to the ventral portion of the plate. Ornamentation of fine tubercles are evenly distributed or arranged in rows following the margins of the plate.

SP (Fig. 9S). The SP of Turrisaspis elektor is represented by three isolated specimens. The spinal plate of Turrisaspis elektor is covered with tubercles that also cover the lateral margin, giving it a serrated appearance. Coarse, slightly forward-pointing serrations are particularly well developed along the medial margin at the caudal end of the SP. Data for the three measurable SPs are listed in Appendix 2. Width of the spinal plate was taken at the midpoint along its length.

\section{Comparison to other groenlandaspidids}

The large sample size for Turrisaspis elektor allows for recognition of variation in size and shape of the dermal elements. The authors feel justified in interpreting this material as a single taxon because the variation within each element is continuous as was demonstrated for the MD in Fig. 10. Although other elements have smaller sample size, they also exhibit continuous variation within different sized specimens. Importantly, this continuous variation in Turrisaspis does not extend to specimens that have been described as Groenlandaspis pennsylvanica and the adults of the two taxa are very different in size. Some elements such as the AL have similar shapes in the two taxa found at Red Hill and in these cases we may be unable to distinguish a juvenile of $G$. pennsylvanica from $T$. elektor. In other cases, elements such as the MD and PDL have very different shapes and ornament in each Red Hill taxon and identification of the two taxa is unambiguous.

The tall median dorsal plate of Turrisaspis elektor is similar to the tall MD plate seen in Tiaraspis sp. (Gross, 1965), Tiaraspis subtilis Gross, 1933, and Africanaspis doryssa Long et al., 1997. The isolated, high-spired MDs of Tiaraspis sp. that were reported from the Late Devonian (Famennian) of Belgium by Gross (1965) have ornamentation of tubercles arranged in wavy rows and coarse serrations along the caudal margin, remarkably like the MD of Turrisaspis. Gross referred these Belgian specimens to Tiaraspis sp. but was skeptical about their provenance since the Famennian was beyond the known temporal range for Tiaraspis. The presence of the high-spired Turrisaspis from the Catskill Formation in Pennsylvania confirms that such forms were present in Euramerica during the Famennian 
and may remove doubt about the provenance of the Belgian specimens. In Turrisaspis and Tiaraspis subtilis the MD is approximately the same height as the PDL. Many features of Tiaraspis subtilis, however, such as the shape of lateral trunk elements and the nature of the head shield elements are quite unlike Turrisaspis elektor. A close relationship between these two taxa is also improbable due to the long temporal gap between their occurrences. In Africanaspis doryssa the MD is about twice the height of the PDL and the symphysial surface on the visceral side of the PDL is nearly half of the height of the entire element (Long et al., 1997). Although a raised crest running from the condyle of the ADL to the centre of the caudal margin is seen in both Africanaspis and Turrisaspis, the ADL and PDL of Africanaspis are not shortened cranially-caudally to the dramatic extent seen in Turrisaspis. Therefore, although Turrisaspis elektor, Tiaraspis subtilis and Africanaspis doryssa share the character of a tall MD with a H/L ratio greater than one, other aspects of their morphology suggest that they are not closely related. With the present knowledge of the phylogenetic relationships within groenlandaspidids it is not clear if a tall MD has evolved several times in groenlandaspidids or only once.

Turrisaspis elektor differs from all species of Groenlandaspis and from Boomeraspis by the high-spired MD, and the tall, narrow plates of the lateral trunk shield. Despite the fact that the dorsolateral plates of the trunk shield are quite unique in Turrisaspis elektor, the head shield and ventral trunk shield are similar to Groenlandaspis antarctica. This may indicate that Turrisaspis is more closely related to Groenlandaspis than to the high-spired, but otherwise distinctive, Tiaraspis and Africanaspis.

\section{Discussion}

The specimens described in this paper as two new species of groenlandaspidid placoderm were all recovered from within the 2-meter-thick fossiliferous zone at the Red Hill site. Within the fossiliferous zone, fossil material comes from two lithofacies that represent different sedimentary environments within a single fluvial system. The most fossiliferous lithofacies is the red, siltstone to fine sandstone beds that are gently-inclined as the result of deposition on shallow channel margins. Most fossil material from this lithofacies is disarticulated although not abraded, suggesting accumulation of slightly transported material near the channel margin. In one horizon within this lithofacies abundant articulated, although poorly preserved, Turrisaspis specimens suggest stranding in a temporary pool as water level fell. Specimens also occur in a laminated grey-green siltstone lithofacies that is interpreted as an overbank pond facies. Articulated specimens from each of these lithofacies suggest that groenlandaspidids lived in different environments, from shallow, quiet-water ponds to the active channels. The shear number of groenlandaspidid specimens recovered from the Red Hill site, relative to other taxa at Red Hill with similar preservation and collecting potentials, suggests that groenlandaspidid placoderms, particularly Turrisaspis elektor, were quite abundant in the fluvial environments represented at the site.

The sedimentology of the Red Hill site and, more generally, the sediments of the Duncannon Member of the Catskill Formation are indicative of deposition in freshwater fluvial environments within a subtropical, seasonal climatic regime (Woodrow, 1985; Woodrow et al., 1995). Additionally, the presence of fragile terrestrial arthropods such as trigonotarbid arachnids (Shear, 2000) and large numbers of intact terrestrial plants reinforce the non-marine interpretation of the Red Hill site. The distinctly non-marine nature of the deposits at Red Hill is another example of the occurrence of groenlandaspidids in freshwater environments during the Famennian. Although most records of groenlandaspidids are from non-marine facies, several authors (e.g., Schultze \& Cloutier, 1996; Anderson et al., 1999) point out that groenlandaspidids are not exclusive to freshwater deposits and are therefore not reliable indicators of freshwater depositional conditions. In Pennsylvania, no trace of groenlandaspidids have been found in the downstream deltaic facies (Sherman Creek Member) of the Catskill Formation or in the contemporaneous Late Devonian marine facies of the Catskill Sea to the west.

Recognizing that Groenlandaspis and other groenlandaspidids may not be absolute indicators of non-marine depositional conditions, it nonetheless seems that they may cautiously be used for recognition of non-marine rocks in the Famennian. At Red Hill, and at Forbes, New South Wales, groenlandaspidids are found in the same faunas with early tetrapods. Thus, within the Famennian, groenlandaspidids may serve as useful environmental indicators for the kind of non-marine environments that favoured the preservation of early tetrapod fossils.

There are distinct similarities between Groenlandaspis pennsylvanica and other species of Groenlandaspis from Europe, Australia, and Antarctica. Such similarities argue for faunal exchange between the Euramerican and Gondwanan landmasses by the late Famennian. Palaeogeographic reconstruction such as Scotese \& McKerrow (1990) that indicate a near-connection or connection between the two landmasses in the Late Devonian seems required to explain this biogeographic pattern. This pattern has been noted in Late Devonian freshwater vertebrates as well (e.g., Daeschler \& Shubin, 1995, with early tetrapods; Ahlberg et al., 2001, with the lungfish Soederberghia).

The genus Groenlandaspis has been recognized from Eifelian, Givetian, Frasnian and Famennian deposits within the Gondwanan landmasses and therefore does not have biostratigraphic utility in that province beyond marking these stages of the Middle and Late Devonian. Within the Euramerican landmass, however, the genus Groenlandaspis occurs only in Famennian strata (Lelievre \& Goujet, 1986) and therefore marks that stage in remnants of the Euramerican Province. Groenlandaspis pennsylvanica and Turrisaspis elektor from Red Hill, Pennsylvania, can be confidently dated to the late Famennian Stage (Fa2c substage) based on palynomorphs. Thus, Groenlandaspis pennsylvanica is among the latest known species of Groenlandaspis. Turrisaspis may have a more restricted range but additional material from other sites, especially comparable material from the Famennian of Belgium mentioned by Gross (1965), needs to be described and a phylogenetic framework needs to be worked out to understand the diversity and interrelationships of groenlandaspidid taxa. Such an analysis is clearly needed so that biogeographic and biostratigraphic schemes can work with a clearer understanding of relationships within the family Groenlandaspididae. 
ACKNOWLEDGMENTS. The authors thank John Long and Zerina Johanson for useful discussions, and Alex Ritchie and Gavin Young for their thoughtful reviews that greatly improved this paper. We also thank N. Douglas Rowe, Norman Delaney, and Pierce Archer for their work at the Red Hill site, and Scott Rawlins for several of the line drawings in this paper. One of the authors (CFM) expertly handled the fossil preparation. The imaging of specimens was done in the Albert M. Greenfield Digital Imaging Centre for Collections at the Academy of Natural Sciences in Philadelphia. This work was enabled by generous supporters of the Academy of Natural Sciences of Philadelphia, National Geographic Society Committee for Research and Exploration grant \#5436-95, and National Science Foundation grants \#DBI 9731886 and \#EAR 9628163.

\section{References}

Ahlberg, P.E., Z. Johanson \& E.B. Daeschler, 2001. The Late Devonian lungfish Soederberghia (Sarcopterygii, Dipnoi) from Australia and North America, and its biogeographical implications. Journal of Vertebrate Paleontology 21(1): 1-12.

Anderson, M.A., J.A. Long, F.J. Evans, J.E. Almond, J.N. Theron \& P.A. Bender, 1999. Biogeographic affinities of Middle and Late Devonian fishes of South Africa. Records of the Western Australian Museum, Supplement 57: 157-168.

Berg, T.M., M.C. McInerney, J.H. Way \& D.B. MacLachlan, 1983. Stratigraphic Correlation Chart in Pennsylvania. Commonwealth of Pennsylvania, Bureau of Topographic and Geologic Survey, General Geology Report 75.

Blieck, A., F. Golshani, D. Goujet, A. Hamdi, P. Janvier, E. MarkKurik \& M. Martin, 1980. A new vertebrate locality in the Eifelian of the Khush-Yeilagh Formation, eastern Alborz, Iran. Palaeovertebrata 9: 133-154.

Chaloner, W.G., P.L. Forey, B.G. Gardiner, A.J. Hill \& V.T. Young, 1980. Devonian fish and plants from the Bokkeveld Series of South Africa. Annals of the South African Museum 81: 127-157.

Cressler, W., 1999. Site-analysis and floristics of the Late Devonian Red Hill locality, Pennsylvania, an Archaeopteris-dominated plant community and early tetrapod site. Doctoral dissertation, University of Pennsylvania, Philadelphia, Pennsylvania, United States of America.

Daeschler, E.B., 1998. Vertebrate fauna from the non-marine facies of the Catskill Formation (Late Devonian) in Pennsylvania. Doctoral dissertation, University of Pennsylvania, Philadelphia, Pennsylvania, United States of America.

Daeschler, E.B., 2000a. Early tetrapod jaws from the Late Devonian of Pennsylvania, USA. Journal of Paleontology 74(2): 301-308.

Daeschler, E.B., 2000b. An early actinopterygian fish from the Upper Devonian Catskill Formation in Pennsylvania, USA. Proceedings of the Academy of Natural Sciences of Philadelphia 150: 181-192.

Daeschler, E.B., \& W. Cressler, 1999. Sampling an early continental ecosystem: Late Devonian bone beds at Red Hill, Clinton County, PA (abstract). Journal of Vertebrate Paleontology 19(3) Supplement: 41A.

Daeschler, E.B., \& N.H. Shubin, 1995. Tetrapod origins. Paleobiology 21(4): 404-409.

Daeschler, E.B., \& N.H. Shubin, 1998. Fish with fingers? Nature 391: 133.

Daeschler, E.B., N.H. Shubin, K.S. Thomson \& W.W. Amaral, 1994. A Devonian tetrapod from North America. Science 265: 639-642.

Davis, M., N.H. Shubin \& E.B. Daeschler, 2001. Immature rhizodontids from the Devonian of North America. Bulletin of the Museum of Comparative Zoology 156(1): 171-187.

Denison, R., 1978. Placodermi. In Handbook of Paleoichthyology, 2, ed. H.-P. Schultze, pp. 1-128. Stuttgart: Gustav Fischer Verlag.

Downs, J.P., \& E.B. Daeschler, 2001. Variation within a large sample of Ageleodus pectinatus teeth (Chondrichthyes) from the Late Devonian of Pennsylvania, U.S.A. Journal of Vertebrate Paleontology 21(4): 811-814.
Gross, W., 1933. Die unterdevonischen Fische und Gigantostraken von Overath. Abhandlungen der Preußischen Geologischen Landesanstalt, N.F. 145: 41-77.

Gross, W., 1962. Neuuntersuchung der Dolichothraci aus dem Unterdevon von Overath bei Koln. Paleontologisches Zeitscrifter, H. Schmidt Festband: 45-63.

Gross, W., 1965. Uber die Placodermen-Gattungen Asterolepis und Tiaraspis aus dem Devon Belgiens und einen fraglichen Tiaraspis-rest aus dem Devon Spitzbergens. Institut royal des Sciences naturelles de Belgique, Bulletin 41(16): 1-19.

Hall, J., 1843. Geology of New-York. Part IV. Comprising the Survey of the Fourth Geological District. Albany (New York): Carroll \& Cook.

Heintz, A., 1932. Beitrag zur Kenntniss der Devonischen Fischfaunen OstGronlands. Skrifter om Svalbard og Ishavet 42: 1-27.

Janvier, P., F. Lethiers, O. Monod \& O. Balkas, 1984. Discovery of a vertebrate fauna at the Devonian-Carboniferous boundary in SE Turkey (Hakkari Province). Journal of Petroleum Geology 7(2): 147-168.

Janvier, P., \& A. Ritchie, 1977. Le genre Groenlandaspis Heintz (Pisces, Placodermi, Arthrodira) dans le Devonien d'Asie. Colloques Researches Academie des Sciences de Paris, series D 284: 1385-1388.

Janvier, P., \& C. Villarroel, 2000. Devonian vertebrates from Columbia. Palaeontology 43(4): 729-763.

Leidy, Joseph, 1856. Descriptions of some remains of fishes from the Carboniferous and Devonian formations of the United States. Journal of the Academy of Natural Sciences of Philadelphia 3: 159-165.

Lelievre, H., \& D. Goujet, 1986. Biostratigraphic significance of some Uppermost Devonian placoderms. Annales de la Société géologique de Belgique 109: 55-59.

Long, J.A., 1995. A new groenlandaspidid arthrodire (Pisces; Placodermi) from the Middle Devonian Aztec Siltstone, southern Victoria Land, Antarctica. Records of the Western Australia Museum 17: 35-41.

Long, J.A., M.E. Anderson, R.W. Gess \& N. Hiller, 1997. New placoderm fishes from the Late Devonian of South Africa. Journal of Vertebrate Paleontology 17(2): 253-268.

McCoy, F., 1848. On some new fossil fish from the Carboniferous period. Annals and Magazine of Natural History 2: 1-10.

Miles, R.S., 1973. An actinolepid arthrodire from the Lower Devonian Peel Sound Formation, Prince of Wales Island. Palaeontographica A 143: 109-118.

Newberry, J.S., 1889. The Paleozoic Fishes of North America. United States Geological Survey Monograph 16: 1-340.

Obruchev, D.V., 1964. Agnatha and Fish. In Fundamentals of Paleontology, vol. 11, ed. Y.U. Orlov, pp. 1-522. Moscow.

Ritchie, A., 1974. "From Greenland's icy mountains... "-a detective story in stone. Australian Natural History 18: 28-35.

Ritchie, A., 1975. Groenlandaspis in Antarctica, Australia and Europe. Nature 254: 569-573.

Schultze, H.-P., 1984. The head-shield of Tiaraspis subtilis (Gross) [Pisces, Arthrodira]. Proceedings of the Linnean Society of New South Wales 107: 355-365.

Schultze, H.-P., \& R. Cloutier, 1996. Comparison of the Escuminac Formation ichthyofauna with other late Givetian / early Frasnian ichthyofaunas. In Devonian Fishes and Plants of Miguasha, Quebec, Canada. eds. H.-P. Schultze \& R. Cloutier, pp. 348368. Münich: Verlag Dr. Friedrich Pfeil.

Scotese, C.R., \& W.S. McKerrow, 1990. Revised world maps and introduction. In Palaeozoic Palaeogeography and Biogeography, Memoir 12, ed. W.S. McKerrow \& C.R. Scotese, pp. 1-21. London: The Geological Society.

Sevon, W.D., 1985. Nonmarine facies of the Middle and Late Devonian Catskill coastal alluvial plain. In The Catskill Delta, Special Paper 201, ed. D.L. Woodrow \& W.D. Sevon, pp. 7990. Boulder: Geological Society of America.

Shear, W., 2000. Gigantocharinus szatmaryi, a new trigonotarbid arachnid from the Late Devonian of North America 
(Chelicerata, Arachnida, Trigonotarbida). Journal of Paleontology 74(1): 25-31.

Sullivan, R.E., S.G. Lucus \& K.A. Randall, 1999. The scapulocoracoid complex of Gyracanthus (Acanthodii: Climatiiformes) and a reassessment of the pectoral region in the Gyracanthidae. Proceedings of the Academy of Natural Sciences of Philadelphia 149: 99-108.

Thomson, K.S., 1968. A new Devonian fish (Crossopterygii: Rhipidistia) considered in relation to the origin of the Amphibia. Postilla 124: 1-13.

Thomson, K.S., 1972. New evidence on the evolution of paired fins of Rhipidistia and the origin of the tetrapod limb, with description of a new genus of Osteolepidae. Postilla 157: 1-7.

Thomson, K.S., \& B. Thomas, 2001. On the status of species of Bothriolepis (Placodermi, Antiarchi) in North America. Journal of Vertebrate Paleontology 21(4): 679-686.

Traverse, A., in press. Dating the earliest tetrapods: A Catskill palynological problem in Pennsylvania. Courier Forschungsinstitut Senckenberg.

Weems, R.E., K.A. Beem \& T.A. Miller, 1981. A new species of Bothriolepis (Placodermi; Bothriolepidae) from the Upper Devonian of Virginia (USA). Proceedings of the Biological Society of Washington 94(4): 984-1004.

Woodrow, D.L., 1985. Paleogeography, paleoclimate, and sedimentary processes of the Late Devonian Catskill Delta. In
The Catskill Delta, special paper 201, ed. D.L. Woodrow \& W.D. Sevon, pp. 51-63. Boulder: Geological Society of America. Woodrow, D.L., R.A.J. Robinson, A.R. Prave, A. Traverse, E.B. Daeschler, N.D. Rowe \& N.A. Delaney, 1995. Stratigraphic, sedimentologic, and temporal framework of Red Hill (Upper Devonian Catskill Formation) near Hyner, Clinton County, Pennsylvania: Site of the oldest amphibian known from North America. In 1995 Field Trip Guide, 60th Annual Field Conference of Pennsylvania Geologists, ed. J. Way, pp. 1-8. Lock Haven, Pennsylvania.

Woodward, A.S., 1891. Catalogue of the Fossil Fishes in the British Museum (Natural History), Cromwell Rd, SW. Pt. II. Elasmobranchii. Trustees: British Museum of Natural History, London. 567 pp.

Young, G.C., 1988. Antiarchs (Placoderm fishes) from the Devonian Aztec Siltstone, Southern Victoria Land, Antarctica. Palaeontographica A 202: 1-125.

Young, G.C., 1999. Preliminary report on the biostratigraphy of new placoderm discoveries in the Hervey Group (Upper Devonian) of central New South Wales. Records of the Western Australian Museum, Supplement 57: 139-150.

Manuscript received 5 May 2000, revised 8 February 2002 and accepted 19 February 2002.

Associate Editor: G.D. Edgecombe.
Appendix 1. Groenlandaspis pennsylvanica. Measurements $(\mathrm{mm})$ of individual plates in the Academy of Natural Sciences, Philadelphia (ANSP). $H$, height; $L$, length.

\begin{tabular}{lclll}
\hline ANSP & element & $\mathbf{H}$ & $\mathbf{L}$ & $\mathbf{H} / \mathbf{L}$ \\
\hline 20753 & MD & 27.0 & 60.0 & 0.45 \\
20755 & MD & 29.5 & 62.0 & 0.48 \\
20777 & MD & 28.0 & 55.0 & 0.51 \\
20727 & AL & 37.5 & 77.0 & 0.49 \\
20940 & AL & 33.0 & 70.5 & 0.47 \\
20740 & AL & 31.3 & 60.5 & 0.52 \\
20743 & ADL & 66.0 & 36.2 & 1.8 \\
20700 & PDL & 66.4 & 44.5 & 1.5 \\
20955 & PDL & 60.0 & 44.0 & 1.4 \\
21132 & PDL & 54.2 & 38.0 & 1.4 \\
20725 & PDL & 62.5 & 53.0 & 1.2 \\
21348 & PDL & 58.3 & 38.3 & 1.5 \\
\hline
\end{tabular}

Appendix 2. Turrisaspis elektor. Measurements $(\mathrm{mm})$ of individual plates in the Academy of Natural Sciences, Philadelphia (ANSP). $H$, height; $L$, length; $W$, width.

\begin{tabular}{lllll}
\hline ANSP & element & $\mathbf{H}$ & $\mathbf{L}$ & $\mathbf{H} / \mathbf{L}$ \\
\hline 20669 & MD & 23.1 & 9.7 & 2.4 \\
20674 & MD & 12.8 & 8.4 & 1.5 \\
20678 & MD & 13.8 & 6.1 & 2.3 \\
20687 & MD & 31.1 & 17.6 & 1.8 \\
20703 & MD & 28.2 & 17.6 & 1.6 \\
20707 & MD & 14.2 & 7.6 & 1.9 \\
20708 & MD & 10.7 & 6.3 & 1.7 \\
20711 & MD & 24.7 & 14.5 & 1.7 \\
20713 & MD & 30.1 & 26.2 & 1.1 \\
20714 & MD & 28.5 & 18.5 & 1.5 \\
20715 & MD & 29.2 & 22.5 & 1.3 \\
20721 & MD & 10.2 & 5.9 & 1.7 \\
20731 & MD & 10.8 & 9.0 & 1.2 \\
\hline
\end{tabular}

\begin{tabular}{|c|c|c|c|c|c|c|c|c|c|}
\hline ANSP & element & H & $\mathbf{L}$ & H/L & ANSP & element & $\mathbf{H}$ & $\mathbf{L}$ & H/L \\
\hline 20736 & MD & 21.4 & 12.2 & 1.8 & 20805 & PL & 13.4 & 14.9 & 0.90 \\
\hline 20756 & MD & 21.6 & 16.0 & 1.4 & 20952 & PL & 12.8 & 14.0 & 0.91 \\
\hline 20757 & MD & 20.7 & 11.7 & 1.8 & 20953 & PL & 13.0 & 15.6 & 0.83 \\
\hline 20759 & MD & 26.6 & 17.9 & 1.5 & 20960 & PL & 20.0 & 23.0 & 0.87 \\
\hline 20786 & MD & 14.4 & 7.1 & 2.0 & 21134 & PL & 9.0 & 11.6 & 0.78 \\
\hline 20787 & MD & 28.5 & 28.1 & 1.0 & & & & & \\
\hline 20790 & MD & 23.2 & 14.9 & 1.6 & & & & & \\
\hline 20797 & MD & 23.2 & 15.4 & 1.5 & ANSP & element & W & $\mathbf{L}$ & W/L \\
\hline 20936 & MD & 13.9 & 8.1 & 1.7 & & & & & \\
\hline 20939 & MD & 22.0 & 17.6 & 1.3 & 20672 & AVL & 28.0 & 38.6 & 0.73 \\
\hline 20944 & MD & 6.9 & 5.3 & 1.3 & 20676 & AVL & 26.0 & 34.0 & 0.76 \\
\hline 20949 & MD & 22.7 & 11.5 & 2.0 & 20680 & AVL & 12.6 & 12.6 & 1.0 \\
\hline 20961 & MD & 16.7 & 15.5 & 1.1 & 20686 & AVL & 9.6 & 12.8 & 0.75 \\
\hline 21297 & MD & 28.7 & 19.0 & 1.5 & 20698 & AVL & 18.8 & 22.9 & 0.82 \\
\hline 21301 & MD & 25.7 & 17.7 & 1.5 & 20751 & AVL & 26.0 & 27.3 & 0.95 \\
\hline 21325 & MD & 23.7 & 12.2 & 1.9 & 20752 & AVL & 29.0 & 29.9 & 0.99 \\
\hline 20754 & ADL & 51.0 & 26.0 & 2.0 & 20771 & AVL & 10.2 & 13.0 & 0.78 \\
\hline 20764 & ADL & 32.0 & 16.0 & 2.0 & 20791 & AVL & 22.7 & 34.7 & 0.65 \\
\hline 20766 & ADL & 31.0 & 17.4 & 1.8 & 21320 & AVL & 21.0 & 31.0 & 0.71 \\
\hline 20789 & ADL & 14.9 & 8.4 & 1.8 & 21418 & AVL & 17.6 & 28.6 & 0.62 \\
\hline 20946 & ADL & 18.3 & 10.0 & 1.8 & 21681 & AVL & 22.2 & 30.2 & 0.74 \\
\hline 21322 & ADL & 38.5 & 22.5 & 1.7 & 20683 & PMV & 10.3 & 13.0 & 0.79 \\
\hline 21767 & ADL & 33.0 & 14.0 & 2.4 & 20693 & PMV & 20.3 & 23.9 & 0.85 \\
\hline 20741 & PDL & 27.0 & 10.3 & 2.6 & 20695 & PMV & 19.0 & 20.0 & 0.95 \\
\hline 20742 & PDL & 46.0 & 18.5 & 2.5 & 20738 & PMV & 12.0 & 17.4 & 0.69 \\
\hline 20761 & PDL & 32.5 & 14.2 & 2.3 & 20937 & PMV & 17.3 & 21.0 & 0.82 \\
\hline 20784 & PDL & 31.0 & 12.7 & 2.4 & 20951 & PMV & 23.0 & 25.5 & 0.90 \\
\hline 21136 & PDL & 41.3 & 17.7 & 2.3 & 21331 & PMV & 18.4 & 22.0 & 0.84 \\
\hline 20682 & AL & 19.5 & 24.9 & 0.78 & 20684 & PVL & 27.0 & 31.0 & 0.87 \\
\hline 20705 & $\mathrm{AL}$ & 21.6 & 31.3 & 0.69 & 20720 & SP & 5.5 & 49.0 & 0.11 \\
\hline 20722 & $\mathrm{AL}$ & 15.9 & 24.2 & 0.66 & 20770 & SP & 6.5 & 51.0 & 0.13 \\
\hline 20726 & AL & 19.3 & 35.0 & 0.55 & 21144 & $\mathrm{SP}$ & 5.0 & 31.7 & 0.16 \\
\hline 20792 & $\mathrm{AL}$ & 18.7 & 30.8 & 0.61 & 20673 & head & 24.4 & 29.6 & 0.82 \\
\hline 20801 & $\mathrm{AL}$ & 16.8 & 27.5 & 0.61 & 20705 & head & 40.0 & 42.0 & 0.95 \\
\hline 20947 & AL & 15.0 & 18.0 & 0.83 & 20747 & head & 27.0 & 30.0 & 0.90 \\
\hline 20950 & AL & 20.8 & 26.5 & 0.78 & 20748 & head & 38.0 & 36.0 & 1.1 \\
\hline 20956 & AL & 15.9 & 24.2 & 0.66 & 20799 & head & 43.0 & 41.1 & 1.0 \\
\hline 21321 & AL & 16.7 & 27.7 & 0.60 & 20957 & head & 43.0 & 44.0 & 0.98 \\
\hline 21328 & AL & 21.7 & 34.2 & 0.63 & 20961 & head & 43.0 & 47.0 & 0.91 \\
\hline 20744 & PL & 22.0 & 22.0 & $\begin{array}{l}.0 J \\
1.0\end{array}$ & 21137 & head & 27.0 & 30.0 & 0.90 \\
\hline 20804 & PL & 14.0 & $\begin{array}{l}22.0 \\
16.0\end{array}$ & 0.88 & 21188 & head & 24.6 & 22.0 & 1.1 \\
\hline & & & & & 21190 & head & 22.4 & 23.0 & 0.97 \\
\hline
\end{tabular}

